\title{
6. An Ethnomusicological Discussion of Bì Té, the Chanted Tales of the Huli
}

\author{
Jacqueline Pugh-Kitingan
}

\section{Introduction}

The Huli inhabit the Tagali River basin and surrounding areas, a region of about 6,180 square kilometres that lies mainly between the altitudes of 1,550 and 3,500 metres. There are no distinct seasons in this part of the world. Daily morning sunshine and afternoon rains encourage the cultivation of the staple sweet potato. The Huli also rear pigs as their most important exchange item, which is used for bridewealth and debt settlement.

An egalitarian society with a cognatic descent system and multilocal residence, the Huli do not live in villages, but in small hamlets dispersed amongst their sweet potato gardens on clan (hämeigini) lands. Each hamlet basically contains two main houses - one for a man, his sons around seven years or older, and any visiting male kin, and the other for his wife, unmarried daughters, younger sons, and any visiting female kin. Huli society has strict gender segregation based on cultural beliefs about behavioural etiquette and bodily pollution, and men and women traditionally do not enter each others' dwellings. The houses are small, closed structures, each with a doorway covered by horizontal wooden slabs. They are built flat on the ground to retain heat during the cold night hours. A fire burns inside each house, and its smoke filters through and helps to preserve the grass roof (figure 1). At night, the house members lie around the fire on the ground or on low, sleeping ledges attached to the wall. ${ }^{1}$

\footnotetext{
1 These observations are based on fieldwork carried out from December 1974 to February 1975 as an undergraduate honours student at Monash University, and later during 1977 and 1978 as a doctoral candidate at the University of Queensland. The texts of the two bi té examples discussed in this chapter were checked and translated in 1976 with Mr. Tege Tandagua, a Huli teacher who was then staying in Brisbane and whose help is gratefully acknowledged. My doctoral candidature (1976-81) was funded under a Commonwealth Postgraduate Research Award, while the field trips in 1977 and 1978 were sponsored by the Amy R. Hughes Scholarship, awarded by the Australian Federation of University Women. Since those days, I have had periodic contacts with various Huli and expatriate friends from the Southern Highlands, but have not had the opportunity to return to Papua New Guinea. For reference, see Peters (1975), Pugh (1975), and Pugh-Kitingan (1977, 1979, 1980, 1981, 1982, 1984, 1986, 1992, 1998a, 1998b, 2005).
} 


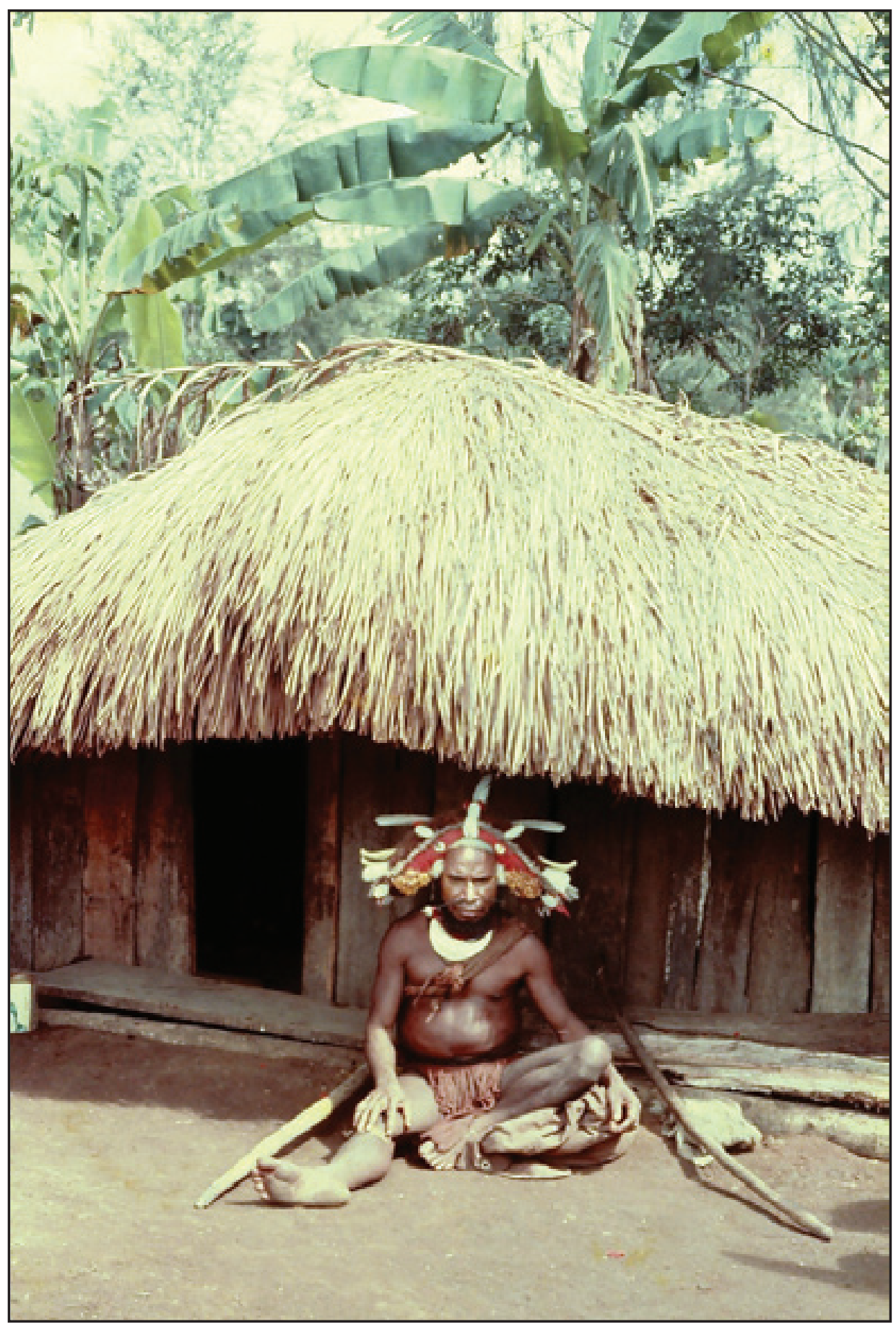

Figure 1. Haralu, a Huli man from Bebenete, in front of his house (photo by author). 
Both Huli men and women are characteristically individualistic, verbose, and domineering, and gender relations may be described as ones of segregated equality. In former times, young unmarried men often joined the celibate harroli group in the bush for a time, to develop their strength for adulthood. During this optional bachelor seclusion, initiates or igiri hâroli ('boy' hāroli) were trained and disciplined by senior hāroli instructors, while growing their hair (a symbol of masculine strength) to be made into wigs. The hâroli were a cult devoted to the veneration of Tiame, a beautiful mythical woman, who according to Huli oral history was murdered in ancient times. Special magical plants called iba gíyawhich were said to have sprouted from her blood and dismembered body partswere kept by the häroli and cuttings were given to initiates (who were then called iba ǵiya) as symbols of their chastity during seclusion. Once a young man had passed his initiation, he could continue on as a harroli or return to society and prepare for marriage. ${ }^{2}$

Bi té ( $b i=$ words, talk, talking; té = story) are long fireside stories, told in the houses of both men and women to entertain children and other relatives during the night hours. The Huli distinguish between bi té and bì hènene ('true words' or 'true stories'), which are the myths and oral history of the people. Glasse (1965:33) uses the term mana for myths, but this is not correct. The Huli describe mána as 'rules' or 'instructions', referring to customary and ritual norms based on supernatural sanction, correctly translated by Lomas (this volume, chapter 5) as 'lore'. Mána ranges from traditional moral values taught to children, to solemn instructions on appropriate behaviour given to hâroli novices by their instructors, as well as ritual specifications for certain ceremonies conducted by other kinds of ritual specialists. Both bi hēnene and bì té may contain simple elements of mána. Thus, bi té can sometimes be used to convey important cultural values to children while entertaining them.

Bì hēnene are usually recited in a speaking voice, while bì té are chanted on three main pitches. Unlike bi hēnene, bi té are usually composed extemporaneously and can last from a few minutes to several hours, depending on the skill and whim of the storyteller (Pugh 1975:10-30, Pugh-Kitingan 1981:332-50, 710-87).

As with other Huli non-ritual musical genres, aptitude, personal interest, and exposure to the genre while young determine the proficiency of a storyteller. If a child grows up in a household where one of the members is skilled in performing bi té, he or she may also develop talent as a storyteller. No instruction is given. Children hear bi té from an early age, and an interested young storyteller develops

2 Information about the hāroli and their practices was graciously given by former hāroli instructors from Bebenete, including the late Senior Land Mediator Madiabe Haroli (Dombe Mia Madiabe), Haraya, Diabe, Igilu, Wanabe, and Yule Tagobe. I am most grateful for help given by my research assistant Mr. Bogaya Newai, who interpreted during our interviews. 
skill through listening to many stories and informally trying out the style. Over time, the talent of this individual becomes recognized by others, as that person is asked to entertain members of the house where they live.

\section{The performance event}

The storyteller usually begins by instructing the listeners "You say $\underline{e}$ [yes]" or even "You say $\underline{\underline{e}}$, or my parents will die." 3 This ensures a regular interjection of the word $\underline{\dot{e}}$, chanted on a level pitch by one of the listeners, which tells the performer that the story is not being wasted on a sleeping audience in the dark. It also serves as a prompting device to help the performer continue with the development of the story.

Bì té are chanted in prose form in which sentences or sections usually end with linking expressions such as lāya ('said') or lārugo ábiyani-ō ('which I said that-o'). Although they are chanted at the end of sections, these expressions are not actually parts of the story, but merely help to maintain the flow of articulation as the performer composes the next sentence. Occasionally the chanted prose might break into poetic verse in passages where one of the characters in the story cries a lament or plays a musical instrument through which poetry is articulated. These chanted poetic passages can also function as linkages between sections in the story or may lead up to a dramatic conclusion.

Bì té usually end simply with the spoken statement ài ōgoni ('that's all'). Within the boundaries of the opening announcement and this concluding expression, the performer is free to develop the narrative theme of the story in any way he or she desires.

Although bi té are normally composed on the spot, some performers develop their own stock of favourite stories, and some chant tales that they heard as children. The skill of the storyteller lies in his or her ability to develop the tale and maintain the flow of words without losing track of the events in the story or boring the listeners to sleep.

\section{Bì té as Huli music}

Bì té performance style resembles relaxed singing, punctuated by the periodic $\underline{\underline{e}}$ interjection by one of the listeners. The Huli, however, do not regard bi té style as singing, but simply say it is bi té, emphasizing the storying function of the genre. Although they perform a wide variety of both vocal and instrumental

3 The underline (_) below a vowel, such as in $\underline{\underline{e}}$ and the $\underline{a}$ in $g \underline{a} w \underline{a}$, indicates nasalization. 
music that uses language, the Huli have distinct classifications for each genre. Singing or íba gána includes men's courting house songs (dàwanda $\underline{\bar{u}}$ ), Christian songs (Ngōdenaga íba gána), and contemporary popular songs heard over the radio. Traditional Huli singing is a group performance, in which men sing in a loud falsetto, and songs have fixed poetic structures. Bi té, however, are rambling solo prose forms that sometimes include poetic episodes, and male storytellers do not perform falsetto. Perhaps bi té musical style can be loosely referred to as chanting. Bi té are not chants, however, and the verb 'chanting' is used here as an alternative to 'singing' to reflect Huli musical concepts and convey the idea of melodic recitation.

Bì té are chanted using a melodic cell of three basic pitches of which the middle one functions as a tonic or tonal centre. The upper pitch sounds a whole tone above this, while the lowest is a semitone or tone below the tonic. Sentences usually begin on the central pitch and feature the falling minor or major third between the outside pitches before resolving back onto the tonal centre. The $\underline{e}$ interjection by one of the listeners also falls on this central pitch at the end of each line (figure 2). ${ }^{4}$

Figure 2. Main pitches used in bì té by Akoari Tamabu, recorded at Hoiebia, 1 January 1975.

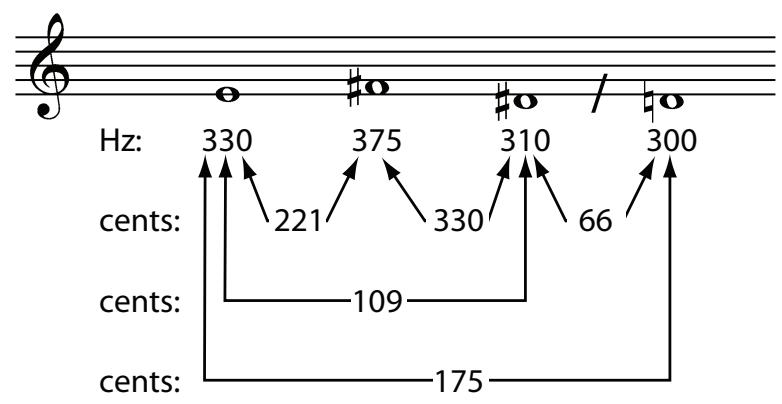

During long bi té, the storyteller very occasionally might include additional melodic material, particularly a descending stepwise movement from a pitch lying a major third above the tonal centre down to the lowest pitch (Pugh 1975:11-17). This then moves back to the original melodic cell, often via a short intervening motif (figure 3 )..$^{5}$ At other times, a performer may occasionally

4 Coincidentally, this pitch arrangement is also used for certain ritual chants, including mànda gāmu ('wig magic') for growing hāroli initiates' hair and íba gíya gāmu for preparing the initiates to receive their íba gíya plants, as well as some kinds of dágia gāmu or women's love charms. The use of this pitch arrangement facilitates the chanting process. Parallelism and alternate changing archaic terms are features of the poetic structures of these chants. In form and function, they are very different from bì té.

5 The performer Akoari Tamabu, who used the pitch arrangements in figures 2 and 3, was a young man of around thirty years at the time of recording, but was renowned as a storyteller among men in the Hoiebia area. 
break into normal speech. This can occur towards the end of a long story as the storyteller grows tired, or at other times it may be a stylistic device to indicate a heightened exclamation by one of the characters in the story.

Figure 3. Additional melodic material used in bì té by Akoari Tamabu, recorded at Hoiebia, 1 January 1975.

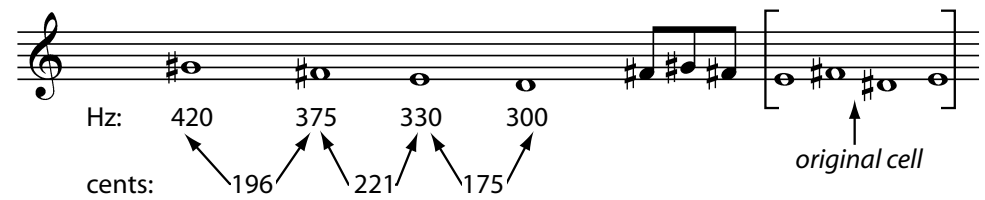

Sometimes when recounting poetry articulated through the orally-resonated double-stringed musical bow gà $\underline{a} \underline{a}$, said to be played by a character in a story, the storyteller may change the melodic material used for chanting the story to that which represents the tuning of this instrument (figure 4). Here the tonic pitch represents that of the outer string of the instrument, while the pitch roughly a major third above this corresponds to that of the inner string, and the highest pitch represents the inner strand when it is stopped by the gà $w \underline{a}$-player's thumb (Pugh 1975:23-28). ${ }^{6}$

As I have shown elsewhere (Pugh-Kitingan 1981, 1984), the basis of Huli music is language. The Huli do not have a specific term equivalent to the English word "music." Except for drumming, which is denoted by permutations of the verb root $b a ́$ ' to hit', all types of musical performance are described with expressions involving words based on $l \bar{a}$ 'to say'. Huli believe that thoughts form in a person's emotional heart (bú), located in the physical heart (búbiri) in the chest. Thoughts rise in breath from the lungs to the mouth and then roll off the tongue as words. The linguistic expression of poetry characterizes most of their music, including the performance of solo musical instruments, such as the gà $w \underline{a}$ bow, the bamboo

\footnotetext{
6 The $g \underline{a} w \underline{a}$ is an orally-resonated, double-stringed musical bow that is strummed with a small thin stick. It is said to have been originally invented by a woman in olden days and is played solo by both skilled men and women (Pugh 1975:148-86; Pugh-Kitingan 1977:220-30; 1981:175-98, 397-447). During gà̀wa performance, the inner string sounds a major third above the outer string. As the performer rapidly strums the strings, he or she stops the inner string with the left thumb, thereby raising its pitch a semitone higher so that is sounds a fourth above the outer strand. The strings on a man's gà wa pass under the wood at the mouth end and over the wood at the longer opposite end, while on a woman's instrument a single strand is looped around the mouth end to form two strings that pass under the wood at the opposite end. A woman thus stops the inner string from above with the pad of her thumb, while a man stops it from below with the plane of his thumbnail. The performer reshapes the external sound energy of the gåaw $\underline{a}$ with the oral cavity to articulate words (the vocal cords remain silent), which are heard in the instrumental timbre sound of the strings and their upper partials (Pugh-Kitingan1977). Stopping and unstopping the inner string gives melodic shape to the speechtones of the words, with a fall to the outer strand pitch at the end of phrases indicating sentence-terminating intonation (Pugh-Kitingan 1984:89-99). In the example of figure 4, the storyteller, the woman Wandome from Walete, was also an expert gà $\underline{\text { wa }}$ player, who tended to tune her inner string somewhat flat, and this interval of a flattened major third was reflected in her performance.
} 
jew's harp or jaw's harp hiriyúla — which are played by both men and womenand, to a lesser extent, two of the gùlupóbe panpipes blown by men (Pugh 1975, Pugh-Kitingan 1977, 1981, 1982, 1984).

Figure 4. Change in melodic material used in bì té by Wandome, recorded at Walete, 13 February 1975.

Original melodic material:

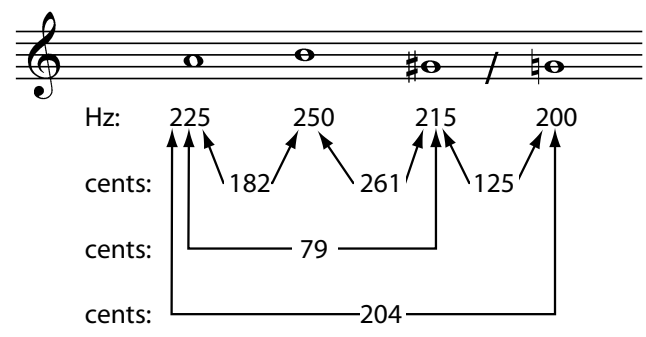

Melodic material for recounting verse played with gàwwa in story:

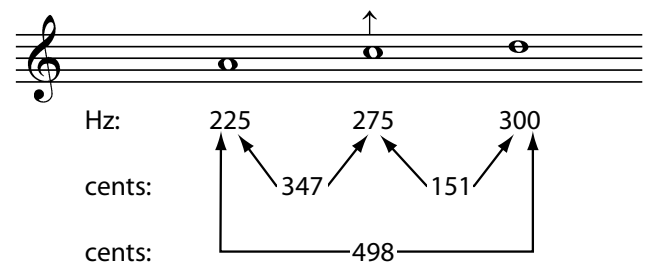

Although they have various expressions for melody (lō pódo, lō póda 'break the speaking'; lō pódo iri dāli, lōpodopoda, lōpodalu 'break the speaking up and down'; gīlinine óre pōdolene 'decoration very breaking'; or simply just pōdolene 'breaking') and ostinato (lā āmuhá or 'going along straight', lit. 'speak straight along a valley stand'), the Huli do not have concepts of metre and rhythm (PughKitingan 1981:150-58). Linguistic articulation produces pace and rhythmic structures in music, while speech-tone largely determines melodic shape within the characteristic pitch arrangement or melodic cell for a specific genre. Huli is a tone language that has three contrastive word-tones: low-rising, high-falling, and mid-level, here indicated with an acute accent ('), a grave accent ('), and a macron $\left(^{-}\right)$, respectively, with sentence-terminating intonation producing a fall on verb affixes at the end of statements (Rule 1977:10; Rule and Rule 1970a:x-xi). ${ }^{7}$

7 In keeping with the practice of Rule and Rule (1970a, 1970b), these marks are shown on the first syllable of the word, although the pitch patterns marked by them pertain to the word as a whole. Somewhat counterintuitively, the Rules used an acute accent (') for high-falling tone and a grave accent (') for low-rising, as the tone marks were used to indicate the relative tone of the first syllable in each word. While I have followed their practice in that respect in my previous writings on Huli, here, for that sake of consistency with Lomas's chapter and at the editors' request, I follow the more standard practice of using the acute accent (') for low-rising tones and the grave (') for high-falling tone. 
In Huli music it is the speech-tones of words that produce the micro-melodic structures within a given pitch arrangement. As will be shown below, this is seen in bi té performance where speech-tone is largely outlined in the melodic patterns between the three pitches, with sentence-terminating intonation producing the resolution onto the central pitch at the ends of sentences. Sometimes the characteristic falling figure between the outside pitches may distort the speechtone of some words somewhat just before the resolution onto the central pitch, as with the words Kándime, lībuni, mbirruagi, and ibugua in Wandome's bì té of figure 7 (figure 5).

Figure 5. Examples of speech-tone distortions by falling third figure, exemplified on the words Kándime, lībuni, mbīruagi, and íbugua in bì té by Wandome, recorded at Walete, 13 February 1975 (from figure 7).

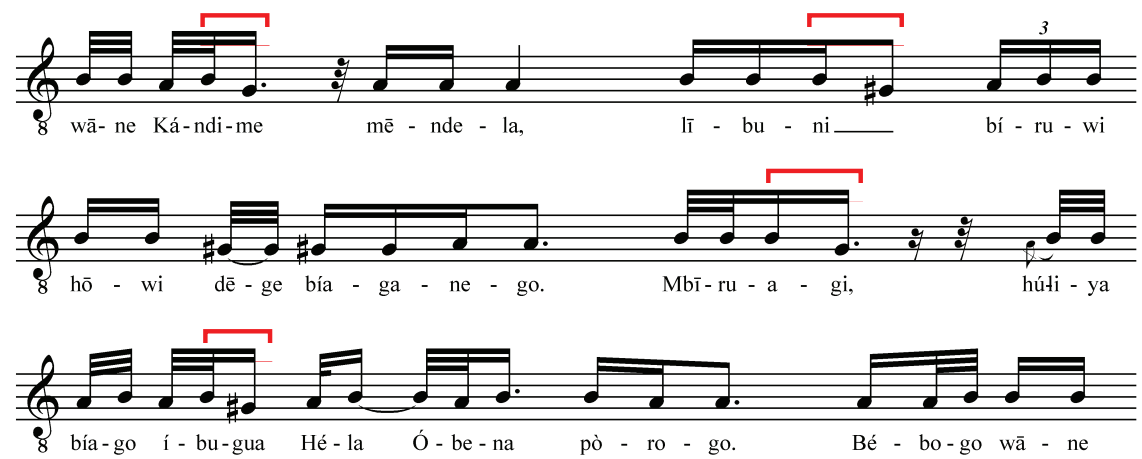

As a storytelling genre, bi té thus exemplifies the fundamental importance of language in Huli music. In addition to the linking expressions and $\underline{e}$ interjections, the basic three-pitch cell and the characteristic recurring falling figure between its outer pitches provide melodic frameworks for telling the story which enable the performer to continue for as long as possible without tiring.

\section{Bì té as Huli oral literature}

Although they may sometimes refer to historical characters, bi té are essentially fiction. Some have happy endings, but most end tragically.

Each story has two or three main characters, among which there are usually a male and a female. Stories frequently tell of events that occur either during a journey or while one of the characters is absent elsewhere. This may reflect the Huli practice of multilocal residence, whereby individuals periodically go to reside with different cognatic kin to maintain influence amongst various ambilineal clans. 
Supernatural elements - including spirits that are often represented by birds such as parrots and magical transformations in which children turn immediately into handsome adults - are common features, as are amazing feats such as a boy constructing a hanging bridge across a river within a few minutes. These stories often describe situations that would be unmentionable in everyday life, such as a young man and a young woman travelling together on a journey, or a celibate hāroli bachelor wooing and marrying a young woman. Although such behaviour is unacceptable in Huli society, it provides entertaining storytelling material.

Bì té composed by women often include descriptions of hāroli painted in bright colours and wearing their ochre-coloured or black crescent-shaped wigs, which are similar to the ceremonial costumes worn by married men during máli dancing, except that hāroli wear their string bags tied across their chests and do not carry drums or dance (figure 6). Women are generally curious about this exclusive male group, and in the past girls eagerly anticipated marrying handsome young men who had completed their terms as häroli. Bì té composed by men frequently feature heroines who display the characteristics that Huli men most admire in women. Heroines are not only beautiful and outspoken, but capable of planting gardens, cutting firewood, rearing and slaughtering pigs, and can even prepare ground ovens - highly capable, in contrast to their incompetent male counterparts in the stories.

\section{Two performances of bì té}

The following examples illustrate two individual performance styles of bi té. The first tells a tragic tale, while the second has an outrageous, comic ending.

\section{Performance by Wandome}

Figure 7 (see appendix 1) shows a bi té by the woman Wandome (figure 8) from Walete in the Tani hämeigini (Pugh-Kitingan 1981:333-36, 711-23). ${ }^{8}$ 


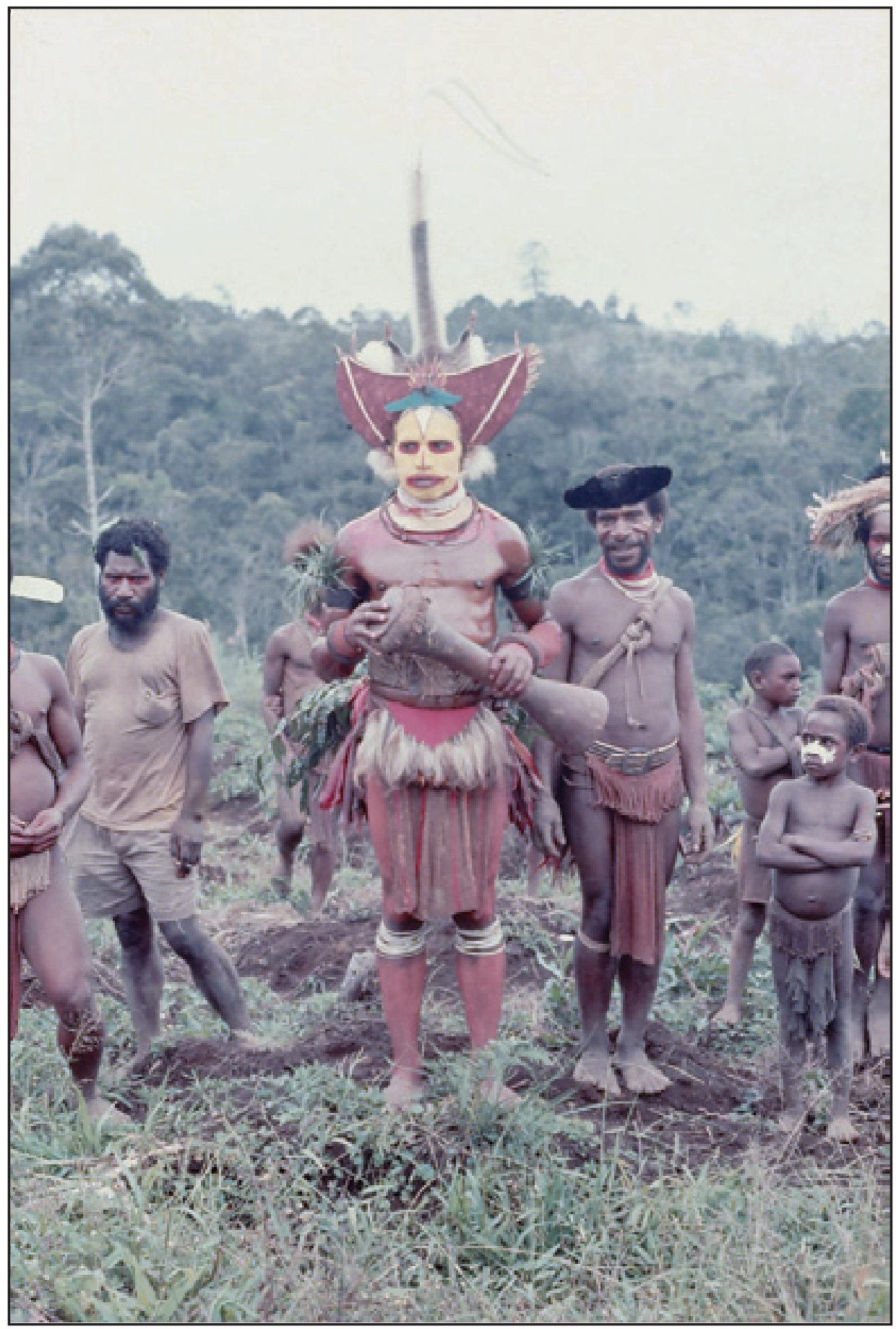

Figure 6. The ceremonial costume of a máli dancer with the crescent-shaped wig and yellow face paint is similar to that worn by häroli bachelors when parading in public as a test, but häroli do not dance with drums (photo by author). 


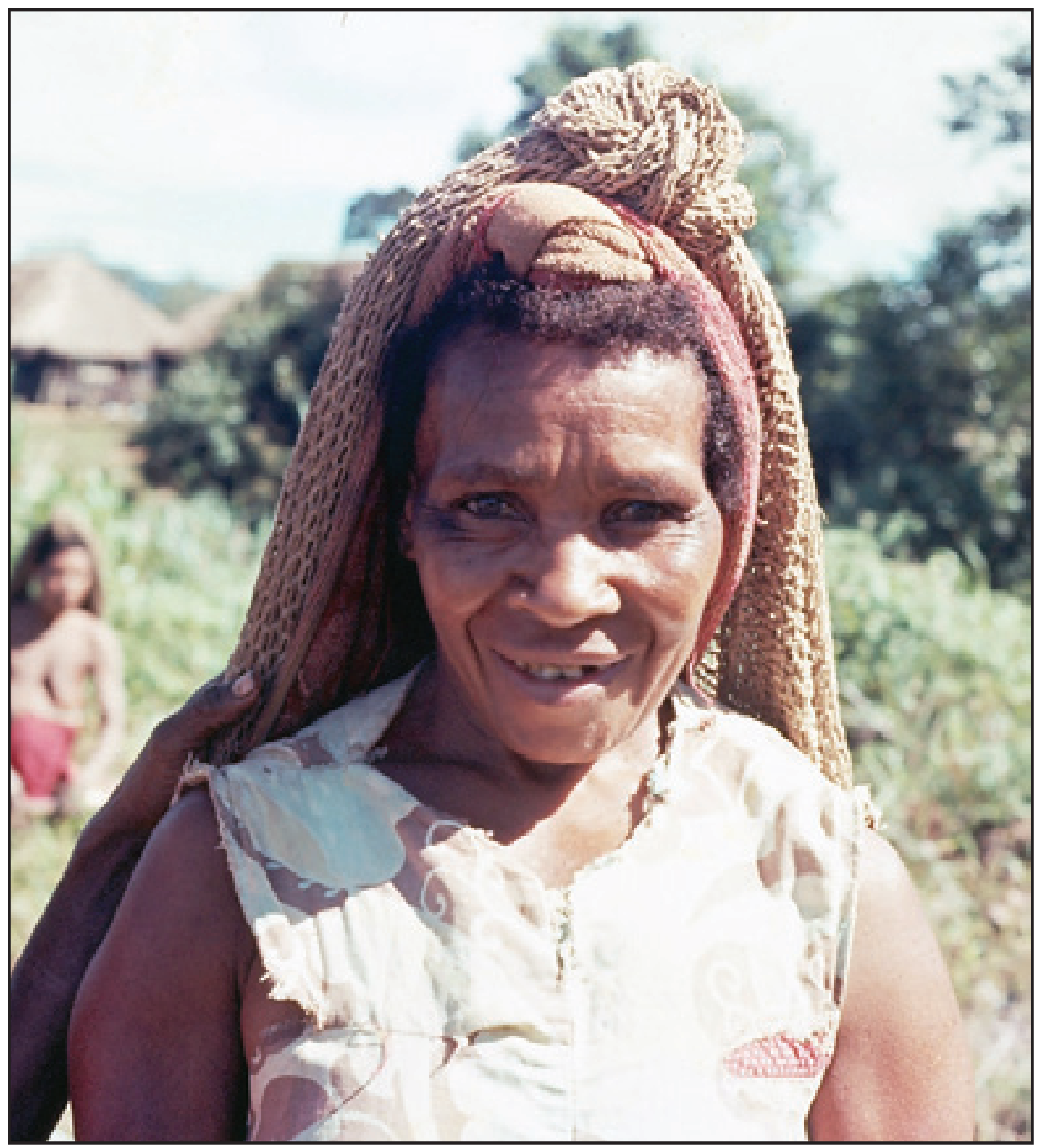

Figure 8. Wandome at Walete in 1977 (photo by author).

Wandome's bi té tells the story of a mythical woman named Bebogo Wane Kandime ('Bebogo's daughter Kandime'). The following synopsis is summarized from the detailed translation after the transcription in figure 7 :

There were once two people, Bebogo's daughter Kandime and her brother, who just lived there all the time. One day, the young man said, "I'm going to the Hele Obena country [to the east of the Huli], but you stay here, Bebogo's daughter Kandime. If you get thirsty, drink from the Gugubia River which I'm damming here; if you hunger for pig meat, eat the wild ones which we caught down there in the bush. But don't go away down there, just stay here." So she stayed there. 
Then one day, she went outside down there. She found some clay ground and, scooping it up, she painted her body. Next, she found a pandanus tree, the leaves of which could be woven into a rain-cape. As she tried to pull down the tree, she found a parrot's egg on top. "This is how I will eat it," she said, "I won't prepare it." So she swallowed it whole.

When she returned home, she sat down and gave birth to a baby boy named Clay Ground Gilara. So Gilara and his mother stayed there all the time and the boy grew up.

As he was getting older, his uncle who had gone to the Hele Obena returned calling out "I'm coming!" When Clay Ground Gilara saw him coming, he said "I'm going to put a bridge across the Gugubia River." His uncle was coming leading two Hele Obena pigs with cut ears, accompanied by two Hele Obena women carrying salt packets in their stringbags.

As they were coming, the boy was putting the bridge across the Gugubia River and his mother was watching. "If I shake when I stand over the middle of the Gugubia, call out 'Clay Ground Gilara my son, my unexpected son, don't fall!", he said to his mother. But when he was standing, shaking on the bridge over the Gugubia, his mother didn't say anything, even though he kept his eyes on her as he shook.

When she didn't say anything, some parrots came screeching and carried the boy away. As they were going, the boy's arm bones turned into wings, and he said "Break off my wing and give it to Mother." That's all.

The tragic ending to this bì té shows that children and kin should not be treated with callous indifference. If the woman had truly cared for her special son, she would have cried out to calm his fear of falling as he balanced precariously above the raging river, while constructing the delicate vine suspension bridge. Since she showed no concern for him, the parrots, from whose egg he had originated, took him from her. She may have feared explaining her unexpected son to her brother, who had warned her not to wander off into the bush. The son's parting gift to his mother of his broken wing bone is a desperate plea for remembrance.

This story contains much magical and supernatural imagery. Bebogo Wane Kandime, the name of the main character, is also the name of a female dama (demon) known throughout the Huli area. The poetic term húliya-which Wandome uses for this character, her brother, and the boy-was often employed in magic chants associated with the harroli cult, and its use here also suggests a magical aspect to these characters. They are able to perform impossible superhuman feats. After discovering a parrot egg at the top of a pandanus palm, the woman swallows it whole, and then gives birth to a baby son on her return 
home. Later as his uncle returns from the east, the youth immediately constructs a suspension bridge across the Gugubia River. The arrival of screeching parrots, which are symbolic of spirits, and the metamorphosis of the boy into a parrot as he is carried off by the birds are also supernatural elements that provide an eerie end to the story.

Nevertheless, since the traditional Huli worldview often perceives the spiritual realm as a parallel to the physical world, the characters also engage in human activities. The main character paints herself in clay and makes a rain-cape of pandanus leaves (symbolic of hoping for a baby - a Huli mother usually carries her new baby wrapped in the pandanus rain-cape inside her stringbag that hangs from her head). Her brother goes on a trading expedition to the Wage or Wola people to the east and returns with pigs, wives, and salt, yodelling as he comes home.

Most of Wandome's bi té is chanted in a soft, melodious voice in prose form with lāya ('said') as the linking expression. She uses three main pitches, of which the highest is a whole tone above the main pitch, and the lowest sounds a minor third and sometimes a major third below the highest (figure 9).

Figure 9. Main pitches used in in bì té by Wandome (figure 7), recorded at Walete, 30 January 1975.

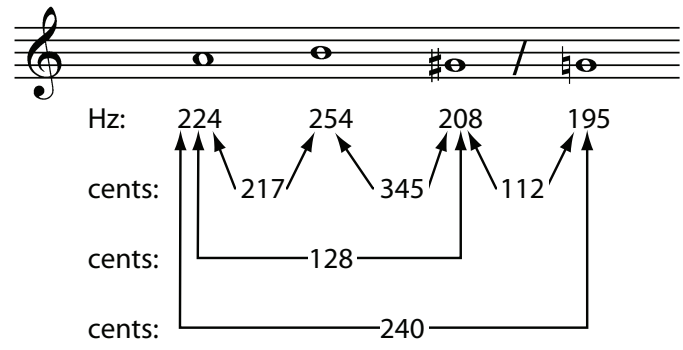

The words of the young man to his mother, however, fall briefly into poetry with the repeat of the expressions "Say 'Clay Ground Gilara my son don't fall!" " and "Say 'My unexpected son don’t fall!,", where búri bóbi lālu mínini and bárina bóbi lālu mínini are poetic alternatives for "unexpected son" (figure 10). The use of poetic parallelisms here helps to capture the attention of the listeners, leading them towards the dramatic conclusion of the story. 
Figure 10. Clay Ground Gilara's poetic plea to his mother, in square brackets (from figure 7).
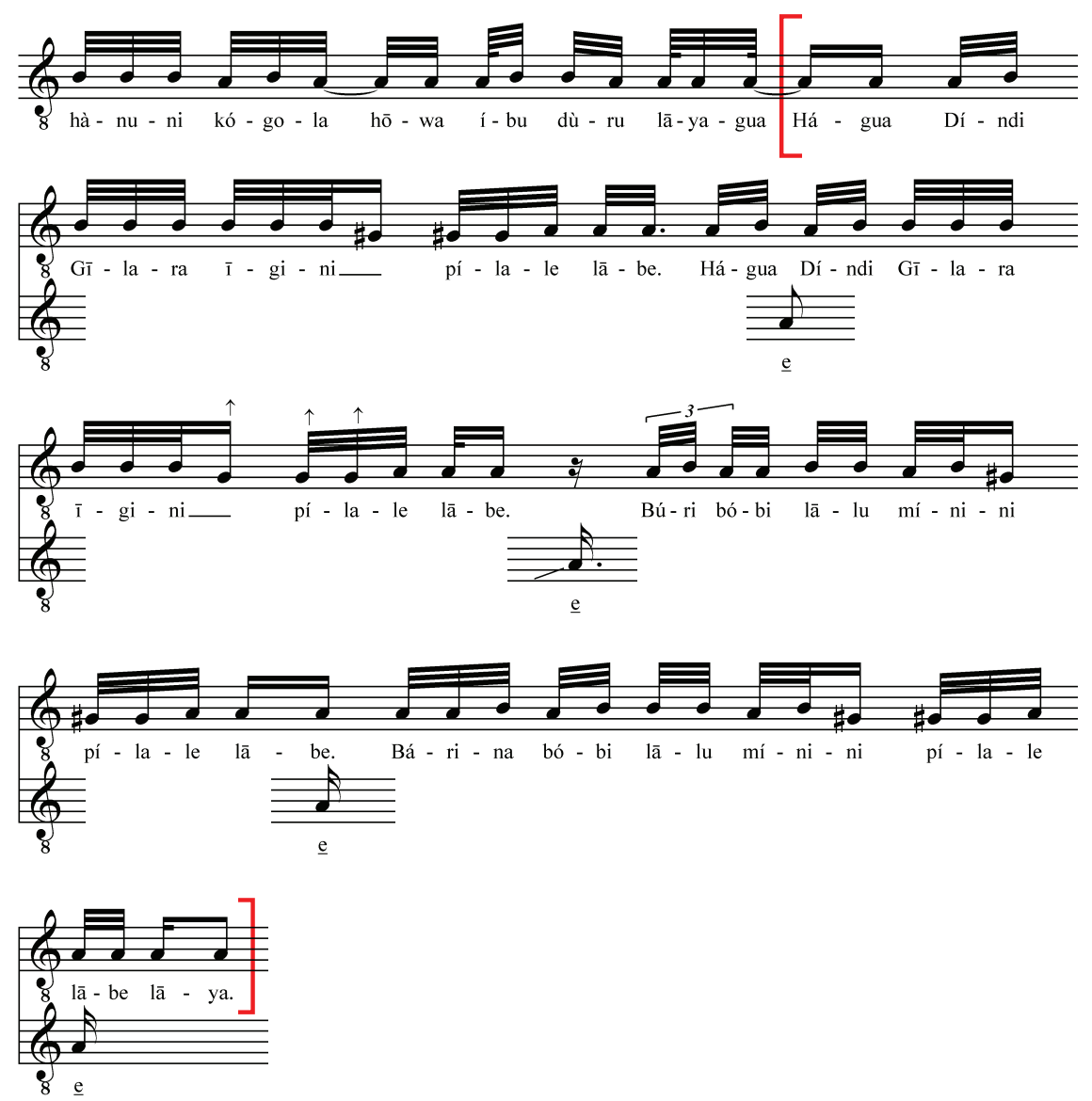

It can be seen from following figure 7 that melodic shapes within the recitation are mainly determined by the speech-tones of the words articulated. Low-rising tone produces rising patterns between the pitches, high-falling tone causes falling figures, while mid-level tone words can be chanted level on any of the three main pitches (but usually the higher two), and sentence-terminating intonation generally produces a level resolution onto the main central pitch at the end of statements. The falling interval of a third between the outside pitches usually corresponds with high-falling tone words, but as mentioned above this is also a stylistic device occurring before sentence-terminating resolution onto the main pitch that assists the storyteller in maintaining the chanted flow. This is a melodic feature of the last syllable of the level tone word igini and also of the low-rising tone word minini in figure 10; in this context of the short repetitive statements made by the character, it emphasizes the sense of poetic verse. 


\section{Performance by Bebalu}

The bì té shown in figure 11 (see appendix 2) was performed by Bebalu (figure 12), who also comes from Walete in the Tani hameigini (Pugh-Kitingan 1981:339-42, 739-52). ${ }^{9}$

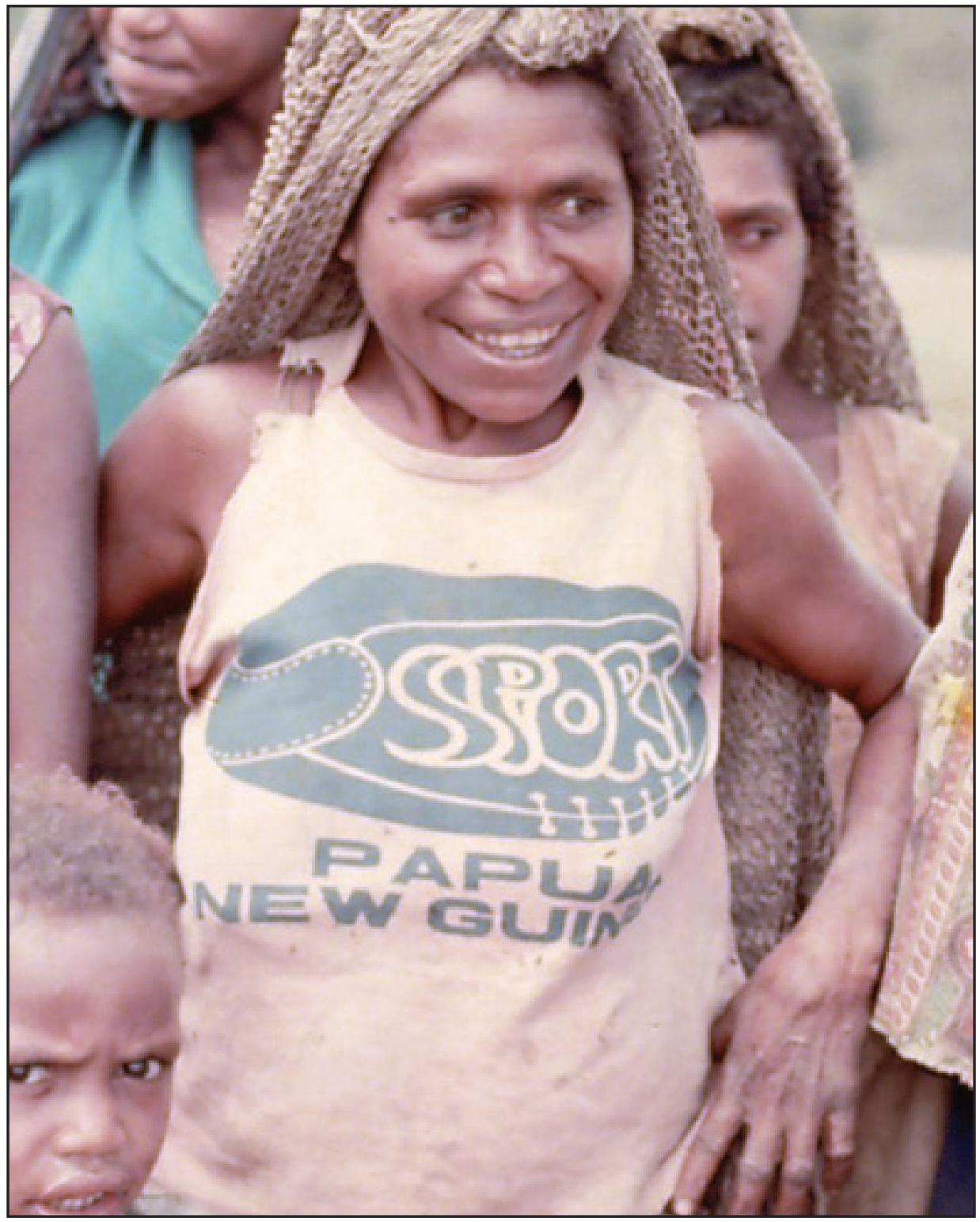

Figure 12. Bebalu at Walete in 1978 (photo by author).

9 This was recorded on 6 February 1975, during a rainstorm; rain can be heard on the zinc roof from the words Ira ibira háyagola. 
The story can be summarized briefly as follows (the literal translation follows the transcription in figure 11):

Listen, I'm telling a story. Once there was a girl who went for a walk. When she had gone quite a distance, she stopped because night was falling. She found a man's house with bundles of sugarcane tied up, and sat down there.

While she was sitting there, an old man came along carrying firewood and put it down. As he was chopping it up, a chip flew off and hit the girl. When the man went to fetch it, he discovered the girl and carried her to where she could lie down and put her there.

After this, the five young men who had gone hunting returned, bringing a possum in their bags for their "father" to cook. He cut the possum into seven portions. When he did that, the five youths said, "Father there are six of us here. Whose is the seventh piece which you've cut?" So the man said "I will eat it myself," and he put it aside to feed the girl when the others were sleeping during the night.

At midnight when he had fed the girl, he tied the long hair of the eldest boy to that of the others and tied their dāmbale aprons and mindibu waist strings all together. Then he sat playing his gà $\underline{w} \underline{a}$ (double-stringed musical bow) through which he said:

"Water flooded the house on the ground.

Water flooded the girl on the ground.

Water flooded the house at Daralu,

I'm decorating in yellow.

I'm decorating Igila.

I'm decorating Debela.

I'm decorating pigs.

I'm decorating Gila and Gilambo."

Because he said that, parrots flew away screeching. Since those five young men were all tied together, how could they stand up? They just sat in a row.

Then those two became husband and wife and their descendants spread everywhere. We are descended from them as it is often said. That's all.

Bebalu's use of the term bālamanda or bālama ānda for the men's house implies that this was the abode of harroli in the bush. This is also suggested by the 
description of the young men having long hair that could be tied together, since part of the training for häroli initiates involved growing their hair to be made into ceremonial wigs. The reference to the young men having caught a possum or tia (here elaborated as tiage and tiabo) may also be an oblique allusion to hâroli. The mythical woman Tiame, venerated in the hâroli cult, is named Tia in the iba gíya gāmu ritual verses chanted to prepare initiates to receive their iba gíya (Pugh-Kitingan 1981:326-27, 698-99). As a woman, the performer would not be familiar with the ritual practices and chants of the häroli, although she would probably know something of the Tiame myth and associate it with the bachelor group. Actual hāroli reportedly did not eat possum or any food baked in ashes, but the mention of tia in the story and its verbal association with Tia or Tiame may also inform the listeners that the men in the story are hâroli. ${ }^{10}$

Since the old man in the story was a senior häroli, the five initiates addressed him as ába ('father'). His association with the young woman and his expression of love for her through the poetry articulated with his gà $\underline{w} \underline{a}$, ended his career as a häroli forever. The reference to screeching parrots flying off at the sound of his instrument not only adds dramatic colour to the story, but symbolizes the loss of his spiritual powers developed through years of discipline away from women and normal society in the bush. This passage is obviously fictitious, since the $g \underline{a} w \underline{a}$ is not usually played by hāroli, unlike the gùlupóbe panpipes that a bewigged man usually carries around and blows as a form of personal diversion to pass time. At the conclusion of their training, häroli initiates have their wigs placed on their heads and each is presented with a set of gùlupóbe.

Bebalu accidentally uses the word hürala from hüra ('woman's reed skirt') when describing the youths' clothing being tied together, and also uses hiriyúla ('jaw's harp' or 'jew's harp', a free aerophone or lamellophone) for the man's musical bow before correcting it to gà̀wa. The term mándibula is an alternative for míndibu (waist strings). Throughout her bì té, she uses lāya ('said') as a chanted, linking expression between sentences.

As shown in the transcription, Bebalu chants most of her story in a singing vocal timbre, before breaking into heightened speech in the last part where she refers to the five initiates sitting tied together in a row, unable to rise. For most of her $b i$ té, until the middle of the gà $\underline{w} \underline{a}$ verse of the old man, she uses three main pitches, of which the lowest sounds either a semitone or whole tone below the main pitch (figure 13). The $\underline{\underline{e}}$ interjection by one of the listeners also rests on the main pitch.

10 Former hāroli claimed that the group ate mostly sweet potatoes, vegetables (edible ferns), and occasionally pig meat (but not fat) that had been steam-cooked in ground ovens. They did not eat food roasted in ashes. This was believed to encourage initiates to grow thick reddish hair that could be made into wigs. 
Figure 13. Main pitches used in bì té by Bebalu (figure 11), recorded at Walete, 6 February 1975.

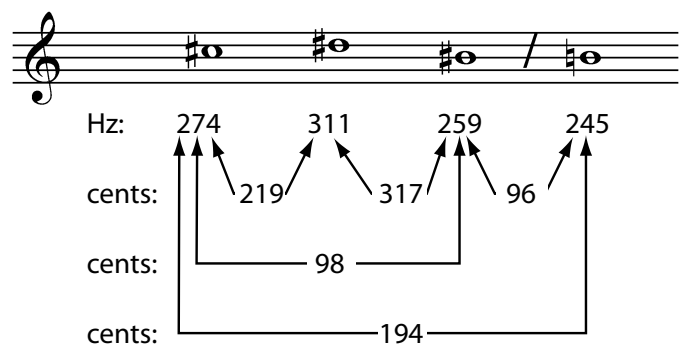

As in Wandome's example, Bebalu's performance features the falling third figure between the outer pitches that sometimes distorts speech-tone, as for the words háyagola, ìgini, léaria, and bárume in figure 14. But usually the speech-tones of words determine the actual melodic microstructures with sentence-terminating intonation producing resolutions onto the central tonic pitch at the end of sentences. The linking expression lāya at the end of sections is also chanted on this pitch, and in most cases this is followed by the $\underline{\underline{e}}$ interjection.

Figure 14. Examples of speech-tone distortions by falling third figure, exemplified on the words háyagola, īgini, lēaria, and bárume in Bebalu's bì té (figure 11).
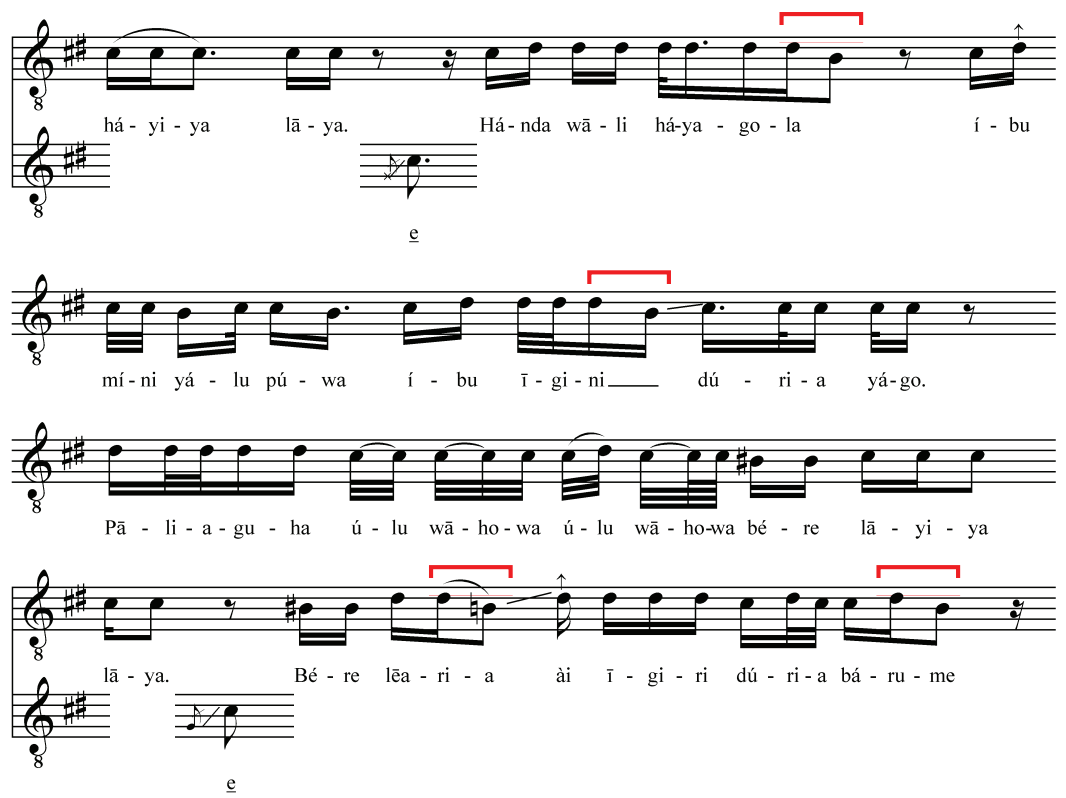
As mentioned earlier, there is no sense of metre or recurring rhythm as in Western music or in the sung tales of the Hagen region as described in chapters 11 and 12. Rather, the inherent linguistic tone patterns of the words determine microrhythmic structures.

A new pitch arrangement emerges during the section recounting the gàdw $\underline{a}$ verse from the words Ígila báli lāro. Here, the lowest pitch is not used. Instead a new pitch sounding a major third above the central pitch is taken up (figure 15). Although this new pitch arrangement is not the same as that of an actual gà $w \underline{a}$, it is Bebalu's way of distinguishing the sound of the instrument from the rest of the story. The tonic now becomes the lowest pitch, and this is reminiscent of gà wa music where the pitch of the outer string sounds as a tonic ostinato below the pitches of the inner strand, and also coincides with sentence terminating intonation as in gà wa poetry. Unlike Wandome, who is renowned for her skill as a gà $w \underline{a}$ performer and hence often chants the same pitch arrangement as that of the bow when recounting gà $\underline{w} \underline{a}$ verses in her bì té, Bebalu is not skilled in this instrument. Thus her new pitch arrangement in this part of her story differs somewhat from the actual instrument.

Figure 15. Pitches used by Bebalu for recounting poetry articulated with $g \underline{a} \underline{\underline{a}} w \underline{a}$ (figure 11).

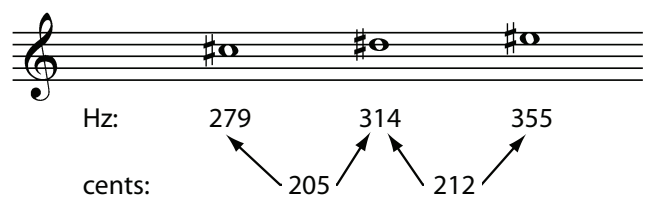

As explained above, when playing the gàdwa, the performer reshapes the sound energy of the instrument with the oral cavity to articulate words (figure 16). These words fall into poetry that often alludes to love. Thus although gà $\underline{w} \underline{a}$ performance requires great skill and is regarded by the Huli as their supreme artistic achievement, it is hardly an activity considered appropriate for a häroli instructor like that in the story here.

The poetry said to have been expressed through the man's gà̀wa in Bebalu's story is typical of Huli love poetry, which consists of repetitions of short lines with a changing word (usually a place name or clan name that identifies an individual) in each line (such as are described and analysed under the rubric of "parallelism" in chapters $1,4,6,8,9,10$, and 11 of this volume). In this story, the flood symbolizes the main character's love for the girl, while the "house on ground" and Dáralu is where the bālama ānda is located. References to yellow ceremonial paint and pigs suggest the man's thoughts of marriage-when he 
will present a number of pigs as bridewealth to the girl's parents-and Ígila, Débela, Gila, and Gílambo are the names of ambilineal clans to whom he is related cognatically.

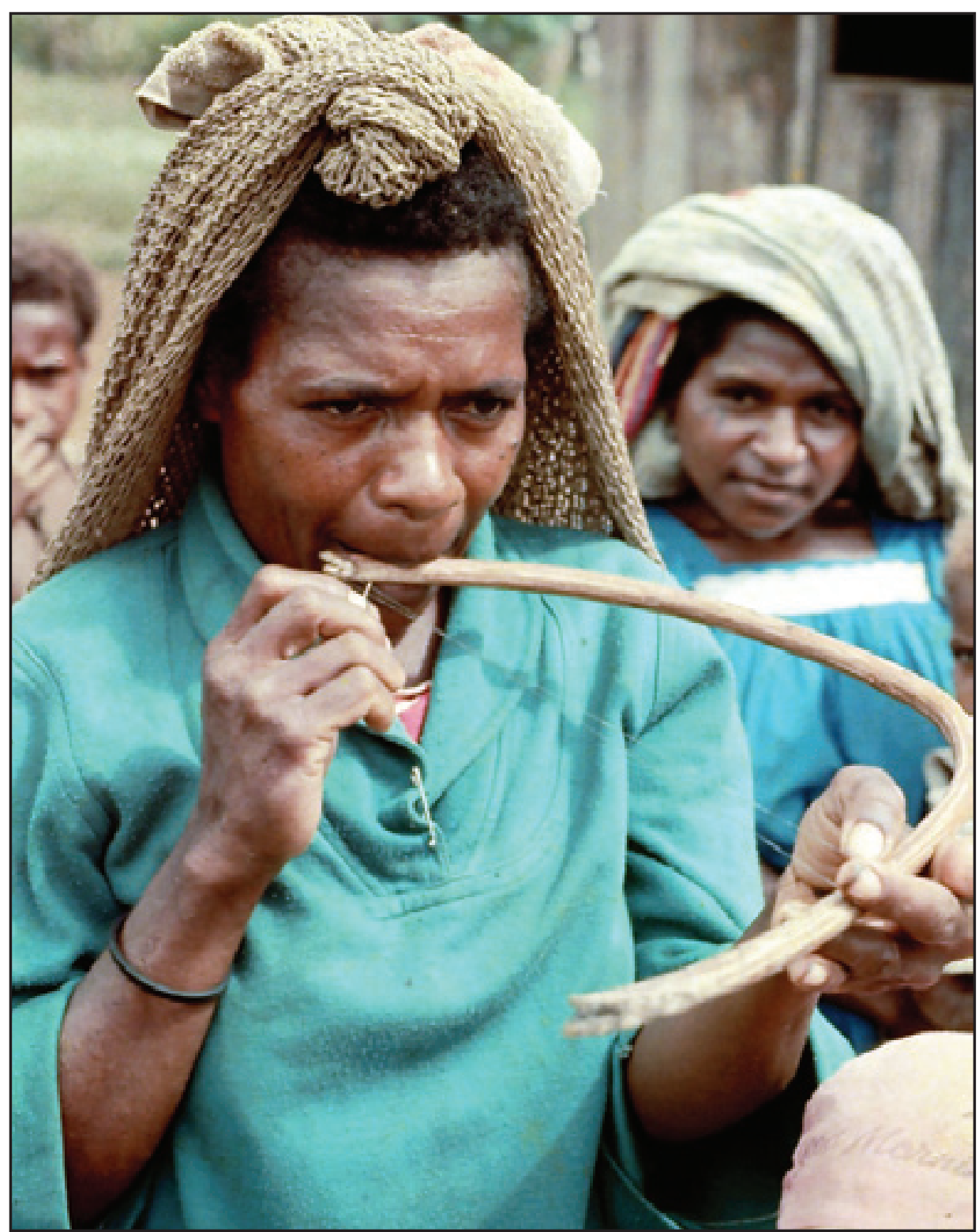

Figure 16. Gagime, a woman from Bebenete, playing her gàdwa (photo by author).

From the word Ígila, the speech-tones of words largely determine the melodic structures within this new pitch arrangement, with verse lines resolving onto the lowest pitch as sentence-terminating intonation. The rising-then-falling melodic patterns of Ígila and Dábela, both of which have low-rising word-tones 
are caused by this. In the case of the line Gila Gilambo báli lāro, where Gila has a high-falling word-tone and Gílambo is low-rising, both syllables of Gila are chanted on the highest pitch, and the two names share a combined, tonallysignificant shape (figure 17).

Figure 17. Poetry articulated by the old man with his gà̀wa in Bebalu's bì té (figure 11).
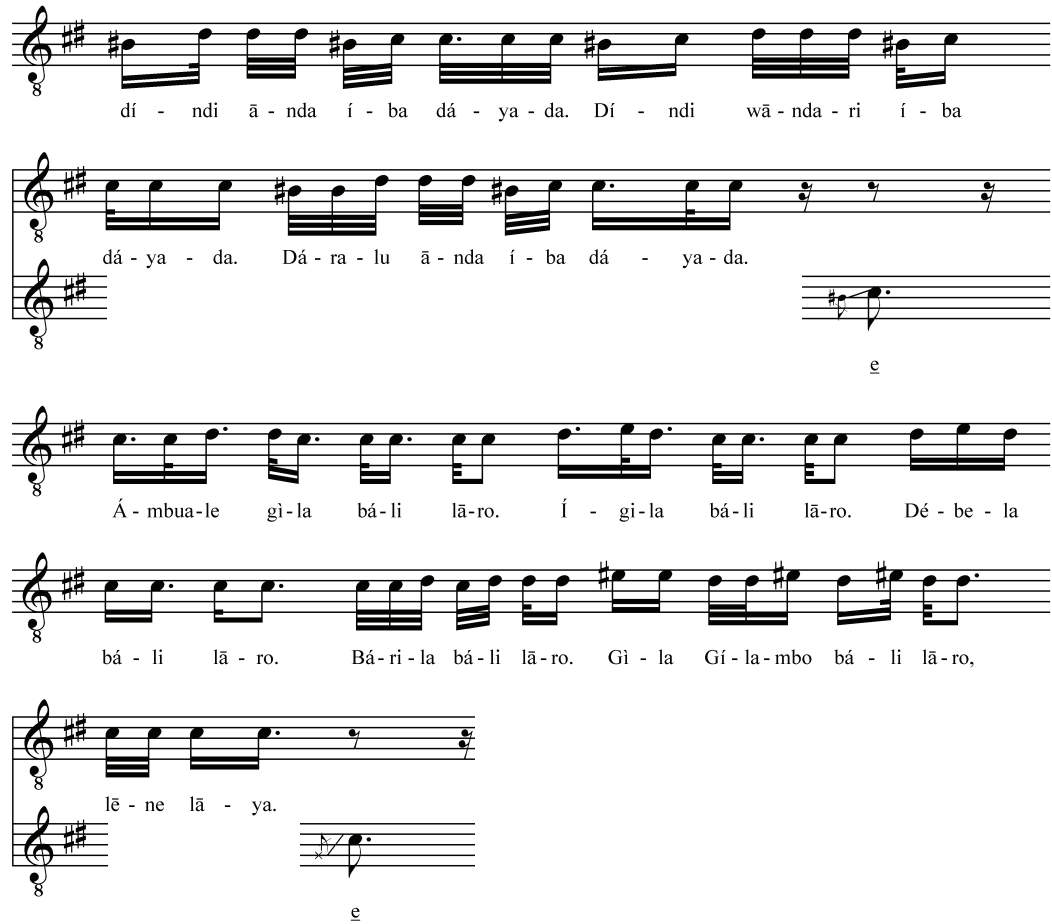

After this section that recounts the man's gàdwa verse, Bebalu breaks into heightened speech as she describes the five häroli initiates who, having been tied together while asleep, are suddenly awakened and unable to rise. Her loud narration captures their stunned surprise at the sound of the instrument's love verse, and her repetition Hèya àu hèyuabe tōba hō bérearia. Hèya àu hèyoabe tōba ho bēreria ("How could they rise up? They just sat in a line") presents a hilarious picture of the five youths tied together in a row. Instead of a sad ending, Bebalu's bi té ends on a happy note by referring to the marriage of the man and the girl.

\section{Conclusions}

The bi té fireside stories of the Huli constitute a musical genre in which the storyteller uses a characteristic melodic cell of three main pitches from which to chant his or her tale. Chanted linking expressions between sections in the story 
and regular melodic interjections of $\underline{\underline{e}}$ ('yes') from one of the listeners, as well as a recurring falling figure between the outside pitches that resolves onto the central main pitch near the ends of statements, help the performer to maintain the flow of words and ideas.

As a musical genre, bi té exemplifies the importance of language in Huli music. Unlike many other cultures in the world, the Huli do not compose "music" and then fit words to the tunes. Rather each Huli genre has its own characteristic pitch arrangement or cell that is used as a vehicle for language articulation. In bi té as in other genres of Huli music, the pace and structure of articulation determines speed and micro-rhythmic patterns, while melody is nearly always shaped by the speech-tones of words with sentence-terminating intonation producing a resolution onto the main pitch at the end of statements. The skill of a musician is determined by his or her ability to articulate rapidly and develop a narrative theme, without losing the flow of ideas or "thoughts from the heart."

Although bì té is a prose form composed of sentences of various lengths, it can also include passages of poetry and heightened speech for dramatic effect in the story. Story themes are usually based around two or three characters, and can include supernatural elements and fantastic episodes. While these stories may provide instruction for children, for example by warning them of the dangers of wandering off into the bush, they are primarily told for entertainment. Hence they may describe activities and relationships that would be unacceptable or even unbelievable in everyday life, such as a senior celibate häroli bachelor falling in love with a young woman. Nevertheless, bi té do reflect both the traditional worldview and life of the Huli, as characters encounter spirits, plant gardens, build houses, construct hanging bridges, undertake journeys, marry and give birth, and join häroli in the bush.

Despite inroads made by outside media, such as radios and cassette or CD players, skilled bi té storytelling continues to be an important genre of nightly entertainment in the houses of both Huli men and women. This is not only because the stories reflect Huli life, but also undoubtedly because bi té as a musical genre springs from the basic need of the individual to express his or her thoughts in language. In expressing these thoughts in chanted story form, the skilled performer is able to engage the listeners and maintain their interest and attention. 


\section{References}

Glasse, Robert M. 1965. "The Huli of the Southern Highlands." In Gods Ghosts and Men in Melanesia, edited by Peter Lawrence and Mervyn J. Meggitt, 27-49. Melbourne: Oxford University Press.

Peters, Bronwyn. 1975. "Huli Music: Its Cultural Context, Musical Instruments and Gulupobe Music." Honours thesis, BA with Honours, Monash University.

Pugh, Jacqueline. 1975. "Communication, Language and Huli Music: A Preliminary Survey." Honours thesis, BA with Honours, Monash University.

Pugh-Kitingan, Jacqueline. 1977. "Huli Language and Instrumental Performance." Ethnomusicology 21 (2): 205-32.

. 1979. "The Huli and Their Music." Hemisphere 23: 84-89.

- 1980. "Language Articulation Using Musical Instruments in the Southern Highlands of Papua New Guinea." Abstract in "Structured Session on Acoustical Aspects of Australasian Music," Tenth International Congress on Acoustics, vol. 1: 51.

. 1981. "An Ethnomusicological Study of the Huli of the Southern Highlands, Papua New Guinea." PhD dissertation, University of Queensland.

. 1982. "Language Communication and Instrumental Music in the Southern Highlands of Papua New Guinea-Comments on the Huli and Samberigi Cases." Musicology 7: 104-19.

-. 1984. "Speech-tone Realisation in Huli Music." In Problems and Solutions: Occasional Essays in Musicology Presented to Alice M. Moyle, edited by Jamie Kassler and Jill Stubington, 94-120. Sydney: Hale and Iremonger.

. 1986. The Huli of Papua Niugini. Recordings by Jacqueline PughKitingan and Bronwyn Peters; commentary, photographs, and map by Jacqueline Pugh-Kitingan. Music of Oceania series, edited by Hans Oesch. Institute for Musicology, University of Basel. Bärenreiter-Musicaphon BM SL 2703. One $30 \mathrm{~cm}, 33$ 1/3 rpm disc.

1992. "Huli Yodelling and Instrumental Performance." In Sound and Reason: Music and Essays in Honour of Gordon D. Spearritt, edited by Warren A. Bebbington and Royston Gustavson, 61-108. St. Lucia: Faculty of Music, University of Queensland. 
. 1998a. "Understanding Music: Timbre: Huli Yodeling." In Australia and the Pacific Islands, edited by Adrienne L. Kaeppler and J. W. Love, 298-99. The Garland World Encyclopedia of Music, 9. Washington: Garland Publishing.

_. 1998b. "Highland Region of Papua New Guinea: Southern Highlands Province: Huli." In Australia and the Pacific Islands, edited by Adrienne L. Kaeppler and J. W. Love, 536-43. The Garland World Encyclopedia of Music, 9. Washington: Garland Publishing.

. 2005. "Dance and Drumming amongst the Huli of the Southern Highlands of Papua New Guinea - the Ethnosemantics, Structure and Change of Group Performance in a Culture of Individuals." In Global and Local Dance in Performance, edited by Mohd Anis Md Nor and Revathi Murugappan, 175-87. Kuala Lumpur: Cultural Centre, University of Malaya and Ministry of Culture, Arts and Heritage Malaysia.

Rule, W. Murray 1977. A Comparative Study of the Foe, Huli and Pole Languages of Papua New Guinea. Oceania Linguistic Monographs, 20. Sydney: University of Sydney.

Rule, W. Murray, and Joan E. Rule. 1970a. Statement of the Phonology and Grammar of the Huli Language. Tari: Asia Pacific Christian Mission.

Christian Mission. 


\section{Appendix 1}

Figure 7. Bì té by Wandome (duration: 2:17)—beginning. An audio file of this example can be found in online item 9 .
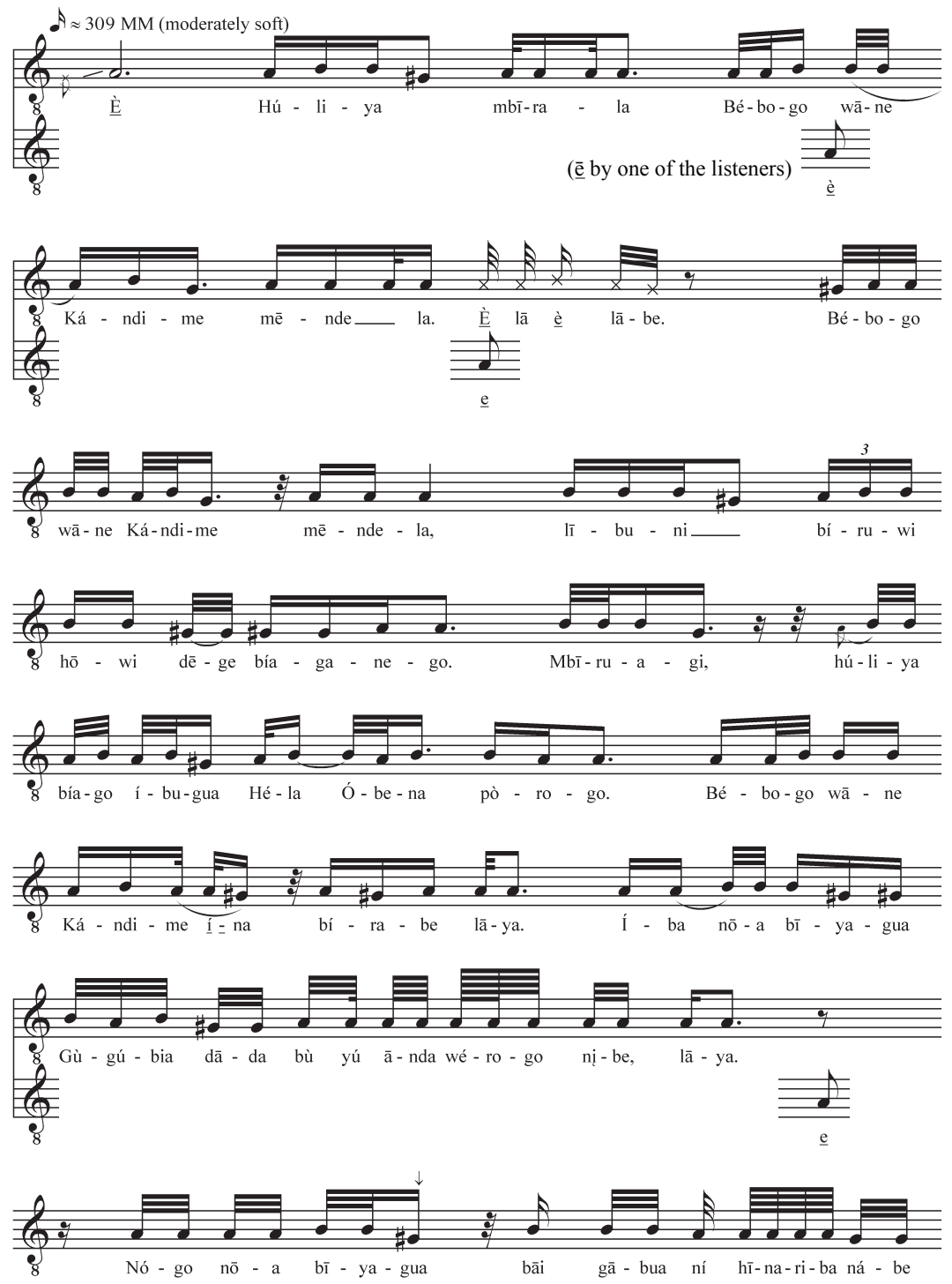
Sung Tales from the Papua New Guinea Highlands
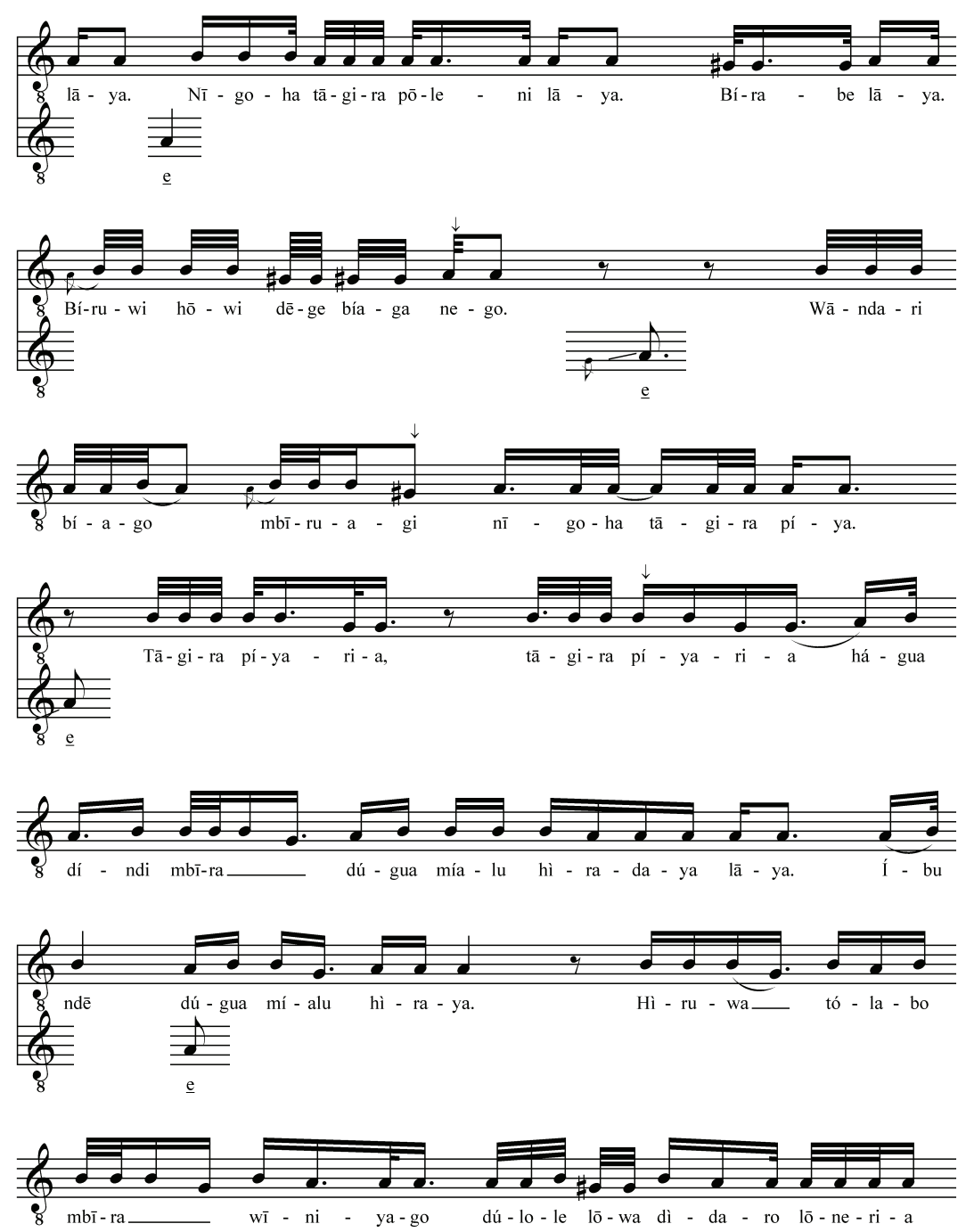

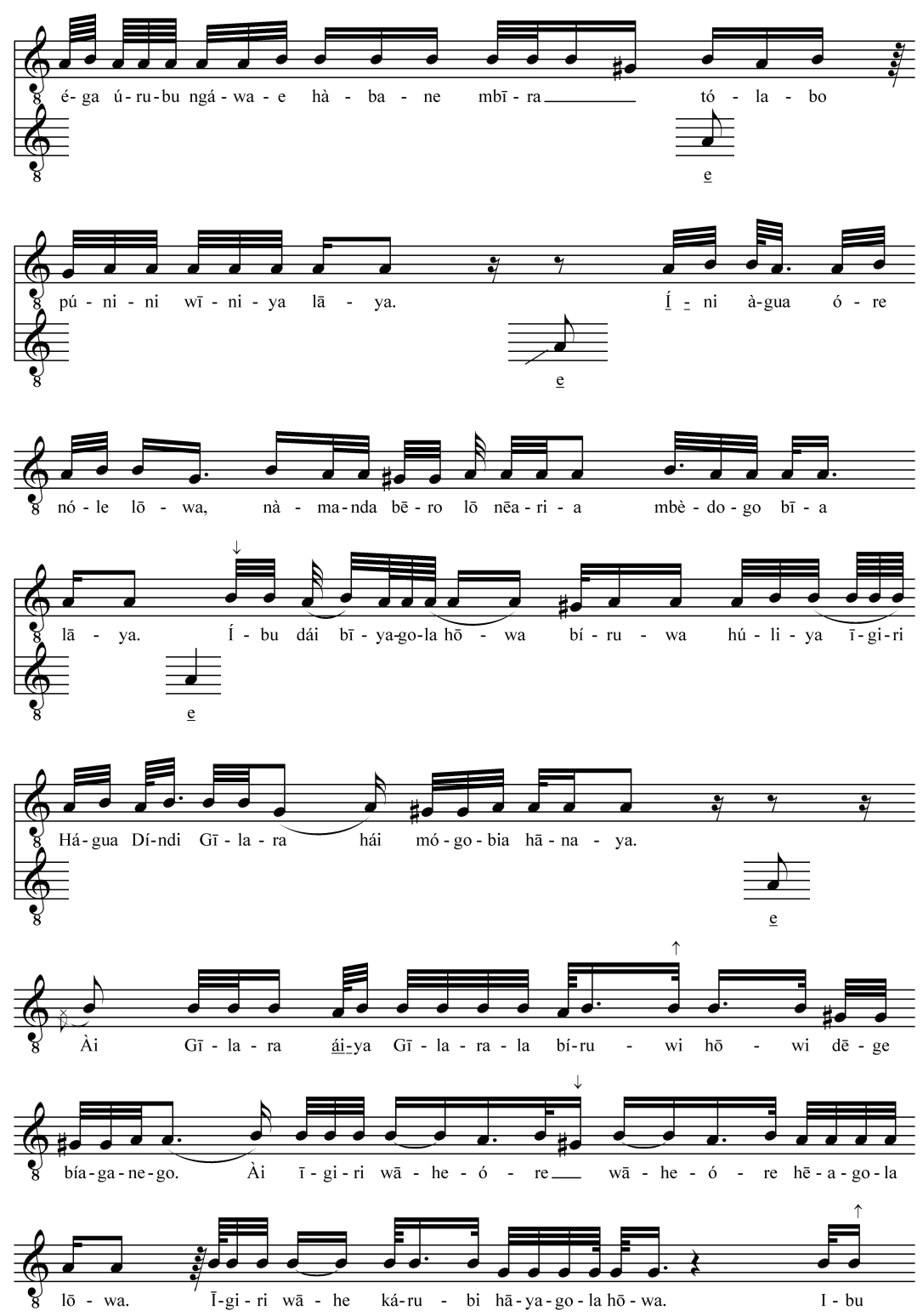

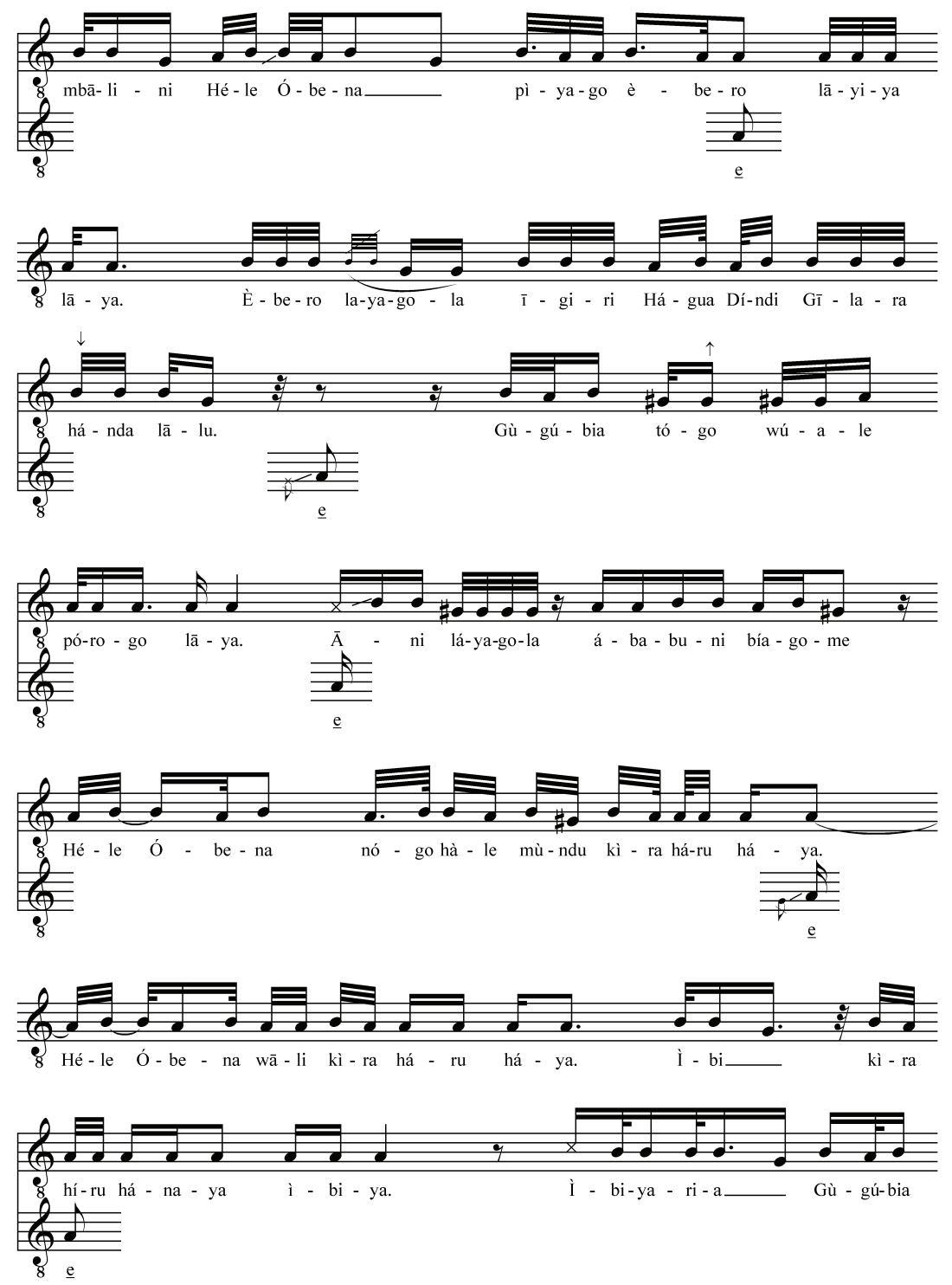

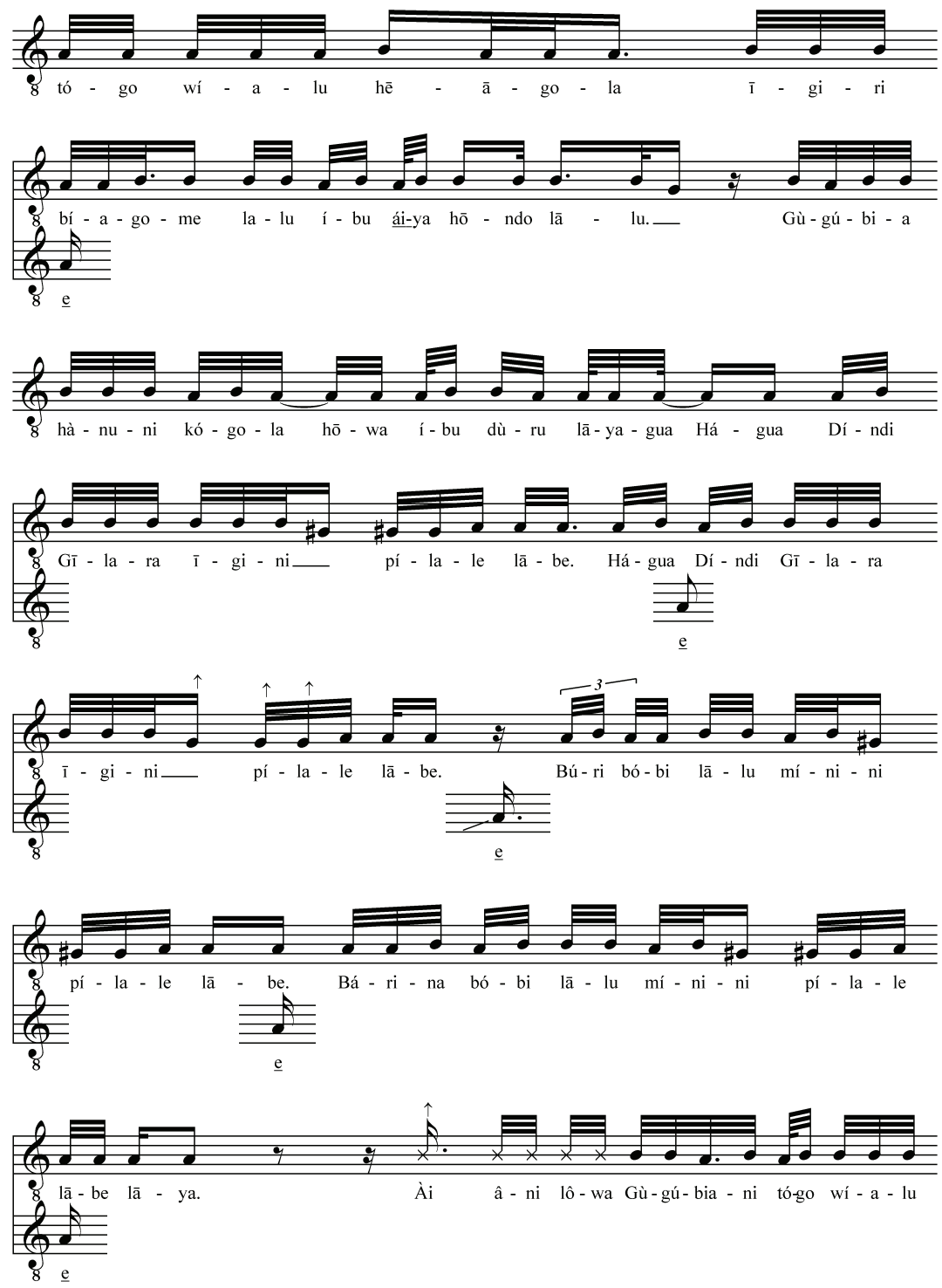

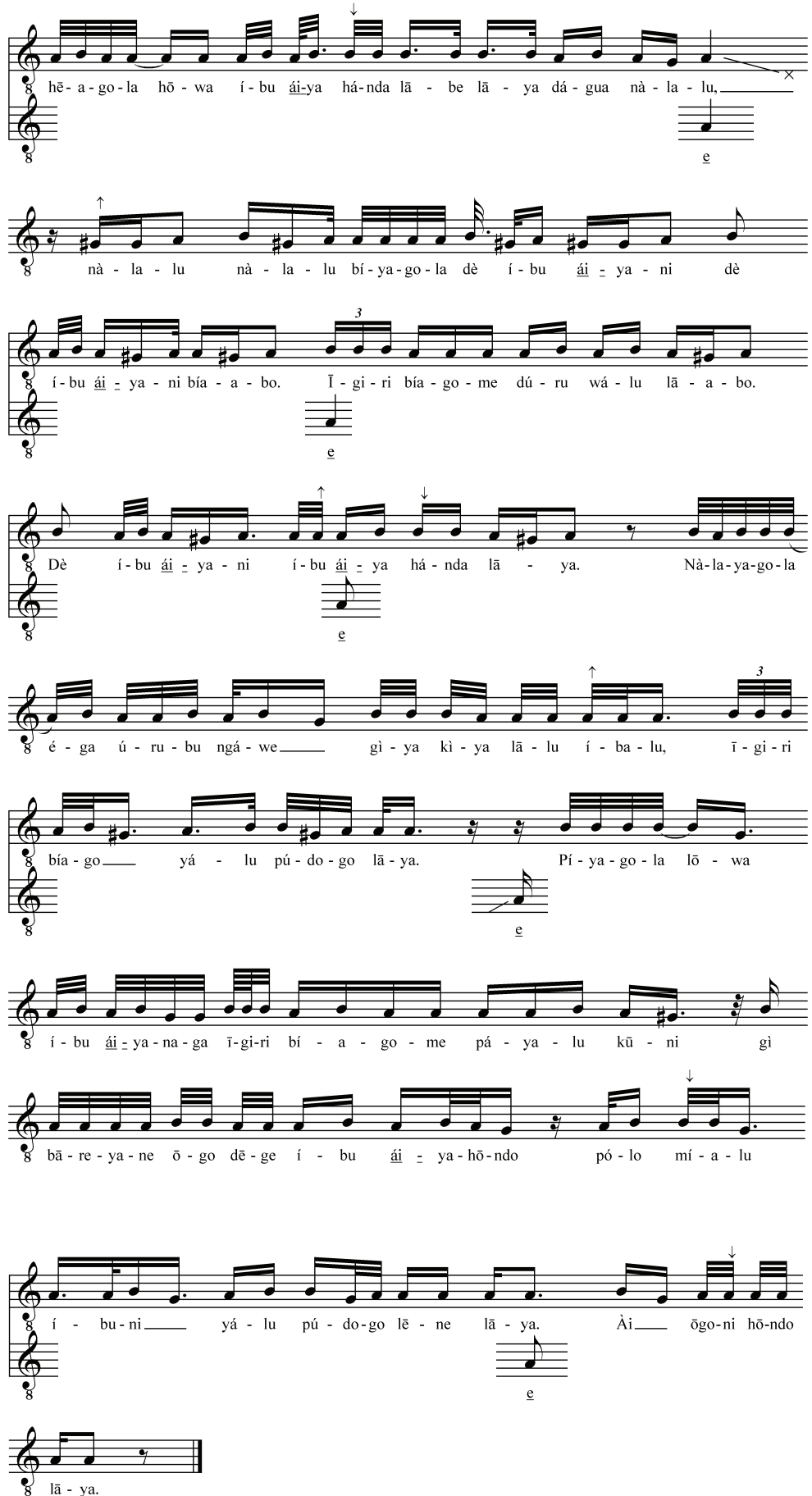
È Húliya mbīrala Bébogo wāne Kándime mēndela.

Yes. Boy first\& Bebego's daughter Kandime second\&.

Yes. There were once two persons, Bebogo's daughter Kandime and a "man.” (Say yes now, say yes later.)
Bébogo wāne Kándime mēndela, lībuni bíruwi hōwi dēge bíaganego. Bebogo's daughter Kandime second\&, they sat stood only which usually do. Bebogo's daughter Kandime and the other, they just lived there all the time.
Mbīruagi, húliya

One day, boy One day, that "man"

bíago íbugua Héla Óbena pòrogo. Bébogo wāne Kándime ína bírabe lāya.

that one he "Hela Obena I'm going. Bebogo's daughter Kandime you sit," said.

said, "I'm going to Hela Obena country. $\quad$ Bebogo's daughter Kandime, you stay here.

Íba nōa bīyagua Gùgúbia dāda bù yú ānda wérogo nábe, lāya.

"Water want to drink if you do, Gugubia stream drained/dammed in which I'm putting drink" he said.

If you want to drink water, drink the Gugubia River which I'm damming in.

Nógo nōa bìyagua bāi gābua ní hīnariba nábe lāya.

"Pig want to eat if you do, wild pig down we (2) caught eat" he said.

If you want to eat pig, eat the wild ones we caught down there in the bush.

Nīgoha tāgira pōleni lāya. Bírabe lāya. Bíruwi hōwi dēge bíaga nego.

"Down there outside don't go" he said. "Sit" he said. Sat stayed only which usual do.

Don't go outside down there," he said. " "Stay here," he said. She just lived there all the time.

Wāndari bíago mbīruagi nīgoha tāgira píya. Tāgira píyaria, tāgira píyaria hágua

Girl that one one day down there outside went. Outside when went, outside when went clay

But one day that girl went outside, down there. When she went outside, she found some clay

díndi mbīra dúgua míalu hìradaya lāya. Íbu ndē dúgua míalu hìraya.

ground one pull out get painted on body said. She then pull out get painted on body. ground and scooping it up she painted her body (said). She then scooped it up and painted her body.

Hìruwa tólabo mbīra wīniyago dúlole lōwa dìdaro lōneria éga úrubu ngáwae

Having painted pandanus one found to weave when said when tried to pull down bird parrot

After having painted herself, she found some pandanus leaves with which to weave a raincape, and when she tried

hàbane mbīra tólabo púnini wīniya lāya. Íni àgua óre nóle lōwa,

egg one pandanus on top found said. "I myself how very I'll eat" saying

to pull them down, she found a parrot egg on the top (said). "This is how I will eat it," she said,

nàmanda bēro lō nēaria mbèdogo bīa lāya. Íbu dái bìyagola

"I'm not preparing" saying when she ate swallow without chewing said. She when she returned

"I won't cook it," so saying she swallowed it whole (said). $\quad$ Then when she returned

hōwa bíruwa húliya īgiri Hágua Díndi Gīlara hái mógobia hānaya. Aì Gīlara áiya stayed sat "boy" boy Clay Ground Gilara banana flower she gave birth to. So Gilara's mother home, having sat down, she gave birth to a boy named Clay Ground Gilara. So Gilara and his

Gīlarala bíruwi hōwi dēge bíaganego. Aì ìgiri wāheóre wāheóre hēagola lōwa.

Gilara\& sit stay only which usually do. Then boy old very old very became was saying. mother just lived there all the time. Then the boy grew very very big.

İgiri wāhe kárubi hāyagola hōwa. Ibu mbālini Héle Óbena pìyago èbero

Boy old mature when he was staying. His "sister" (uncle) Hele Obena which went "I'm coming"

The boy grew up to maturity. His uncle who had gone to Hele Obena country came calling out, 
lāyiya lāya. Èbero layagola igiri Hágua Díndi Gīlara hánda lālu. he shouted said. "I'm coming" when he said boy Clay Ground Gilara look saying.

"I'm coming" (said). When he said "I'm coming," the boy Clay Ground Gilara was watching.

Gùgúbia tógo wúale pórogo lāya. Āni láyagola ábabuni bíagome "Gugubia bridge I will put I'm going, see" he said. Then when he said that uncle that one "I'm going to build a bridge across the Gugubia River," he said. Then when he had said that, his uncle came

Héle Óbena nógo hàle mùndu kìra háru háya. Héle Óbena wāli kìra háru háya.

Hele Obena pig ear cut two was looking after. Hele Obena women two were looking after. bringing two pigs with cut ears from Hele Obena country. Two Hele Obena women were looking after the pigs.

İbi kìra híru hánaya ibiya. İbiyaria Gùgúbia tógo wialu Salt two packet were carrying in string bag came. While they were coming Gugubia bridge puttting They came carrying two packets of salt in their string bags. While they were coming, that boy was building

hēāgola ìgiri bíagome lalu íbu áiya hōndo lālu. Gùgúbia hànuni kógola when it was standing boy that one saying his mother look saying. "Gugubia in the middle where I stand the bridge across the Gugubia River and his mother was watching. "If I shake when I'm standing over

hōwa íbu dùru lāyagua Hágua Díndi Gĩlara ìgini pílale lābe. Hágua Díndi Gĩlara ìgini standing if I shake 'Clay Ground Gilara son don't fall!' say. 'Clay Ground Gilara son the middle of the Gugubia, say 'Clay Ground Gilaria, my son, Clay Ground Gilara, my son,

pílale lābe. Búri bóbi lālu mínini pílale lābe. Bárina bóbi lālu mínini pílale lābe lāya. don't fall'say. 'Unexpected son don't fall!'say. 'Unexpected son don't fall!' say” said. don't fall,' say. 'My unexpected son, don't fall!' say. 'My unexpected son, don't fall!,' say,’ he said.

Ài àni lōwa Gùgúbiani tógo wíalu hēagola hōwa íbu áiya hánda lābe lāya Then having said, on Gugubia bridge putting when he was there standing his mother didn't say he said Having said that, when he was standing on the bridge over the Gugubia, his mother wouldn't say what he

dágua nàlalu, nàlalu nàlalu bíyagola dè íbu áiyani dè íbu áiyani bíaabo. like didn't say, didn't say, didn't say; when he did that eye his mother on eye his mother on kept doing. told her, she didn't say, didn't say, didn't say it; when he did that, he kept watching and watching his mother.

Igiri bíagome dúru wálu lāabo. Dè íbu áiyani íbu áâya hánda lāya. Nàlayagola éga Boy that one kept shaking. Eye his mother on his mother look said. When she didn't say bird That boy kept shaking. He kept watching his mother in anticipation. When she didn't say that,

úrubu ngáwe gìya kìa lālu íbalu, ìgiri bíago yálu púdogo lāya. Píyagola lōwa ibu parrot screeching noise said came boy that one carried away said. When they went saying, his some parrots came screeching and carried that boy away (said). When they went off, that

áiyanaga ìgiri bíagome páyalu kūni gì bāreyane ōgo dēge íbu áîya-hōndo pólo míalu íbuni yálu mother's son that one bones arm wings here only he "Mother to break give, to her take" boy's arm bones here were only wings and he said, "Break off my wing and give it to Mother"

púdogo lēne lāya. Ài ōgoni hōndo lāya.

said (historic tense) said. So that look said.

(said). $\quad$ So that's all (said). 


\section{Appendix 2}

Figure 11. Bì té by Bebalu (duration: 2:27)—beginning. An audio file of this example can be found in online item 10 .
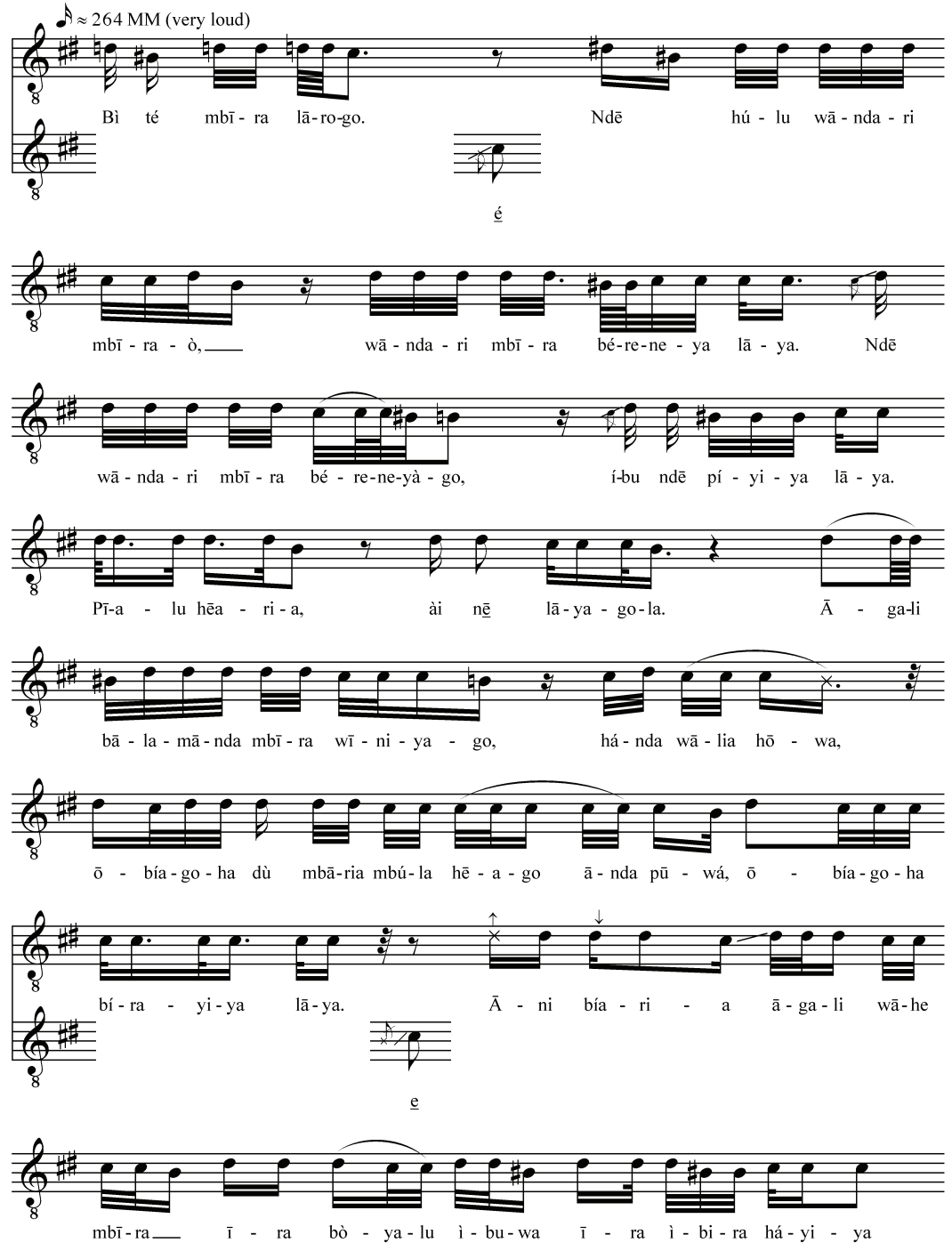

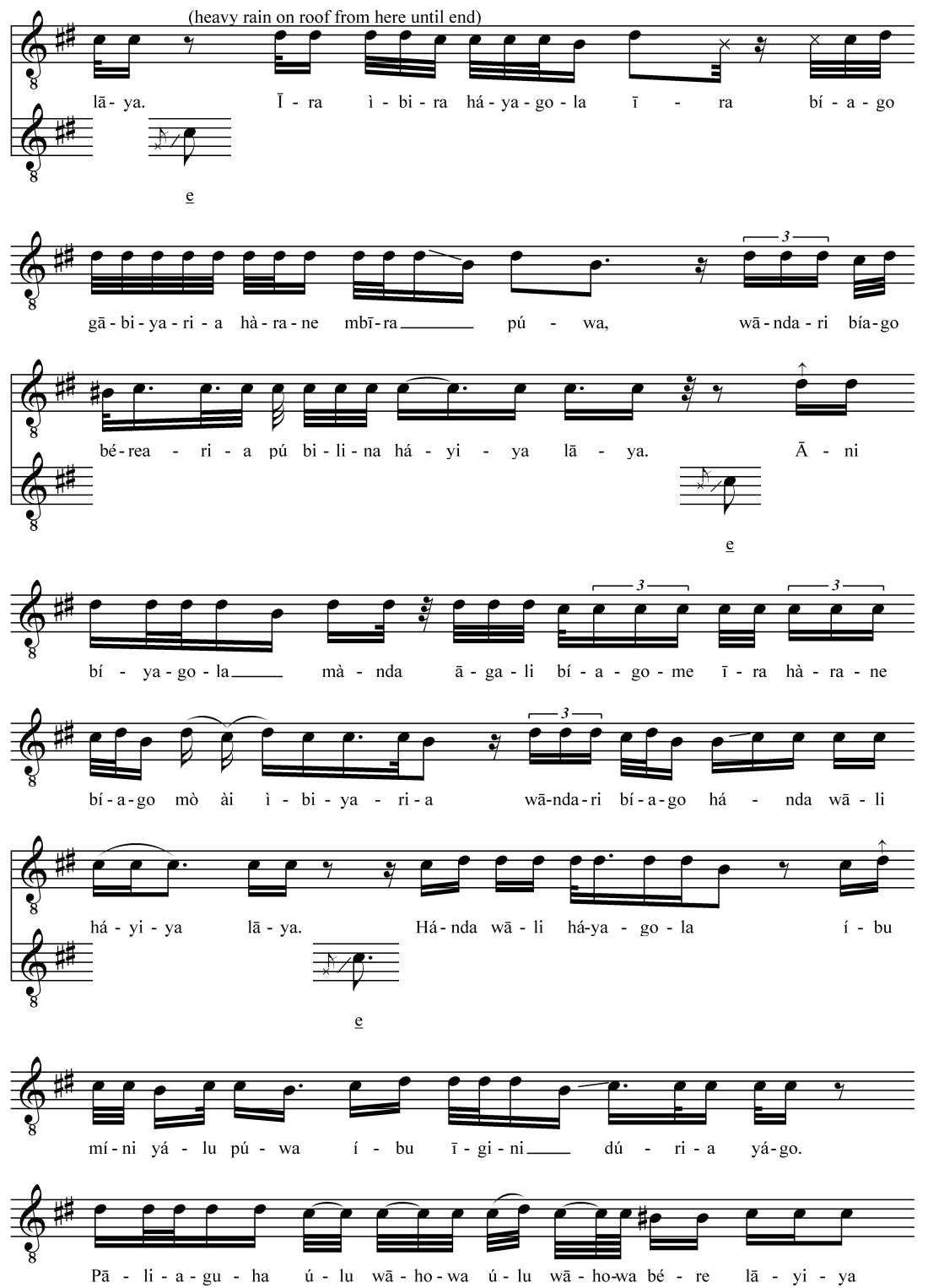

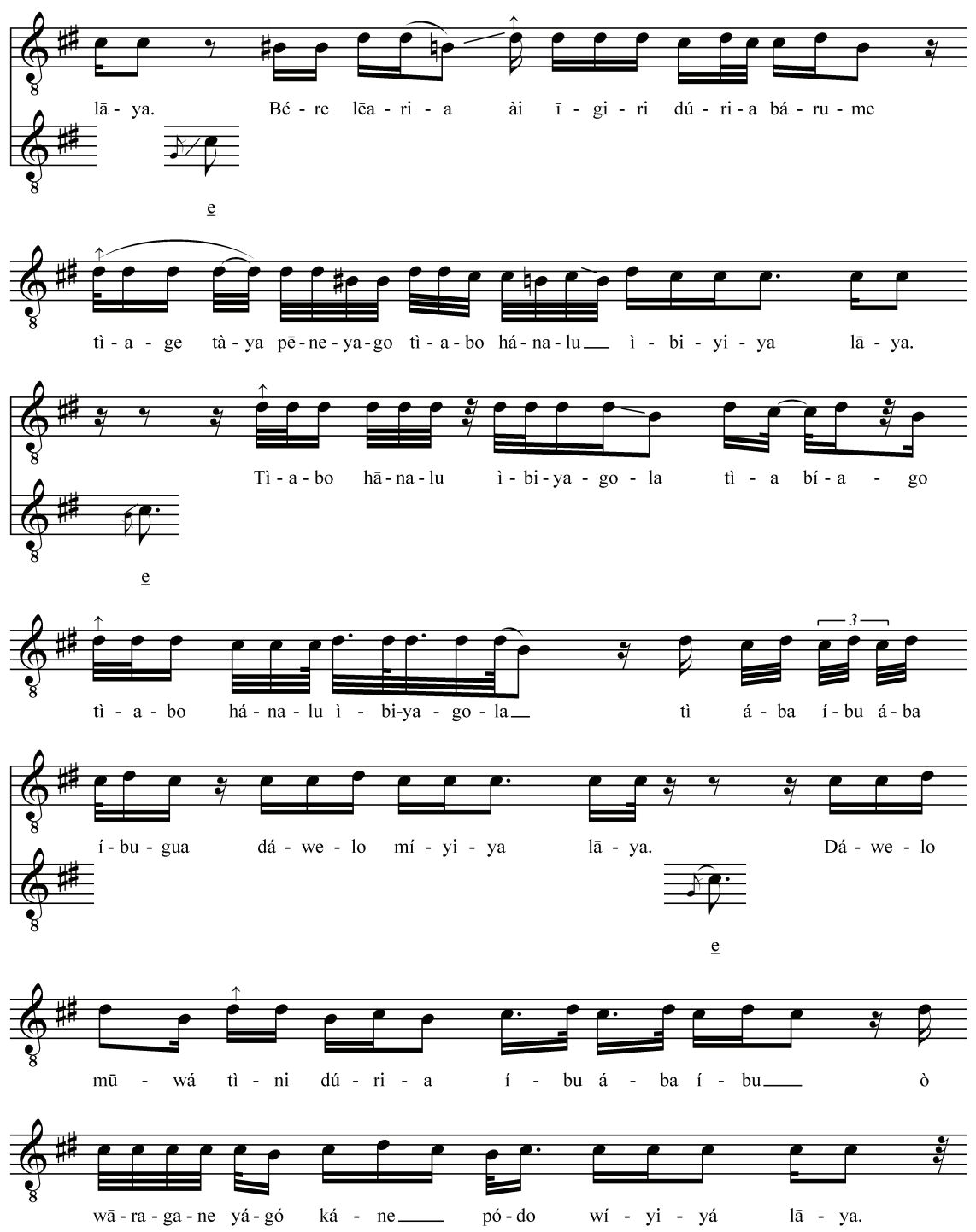

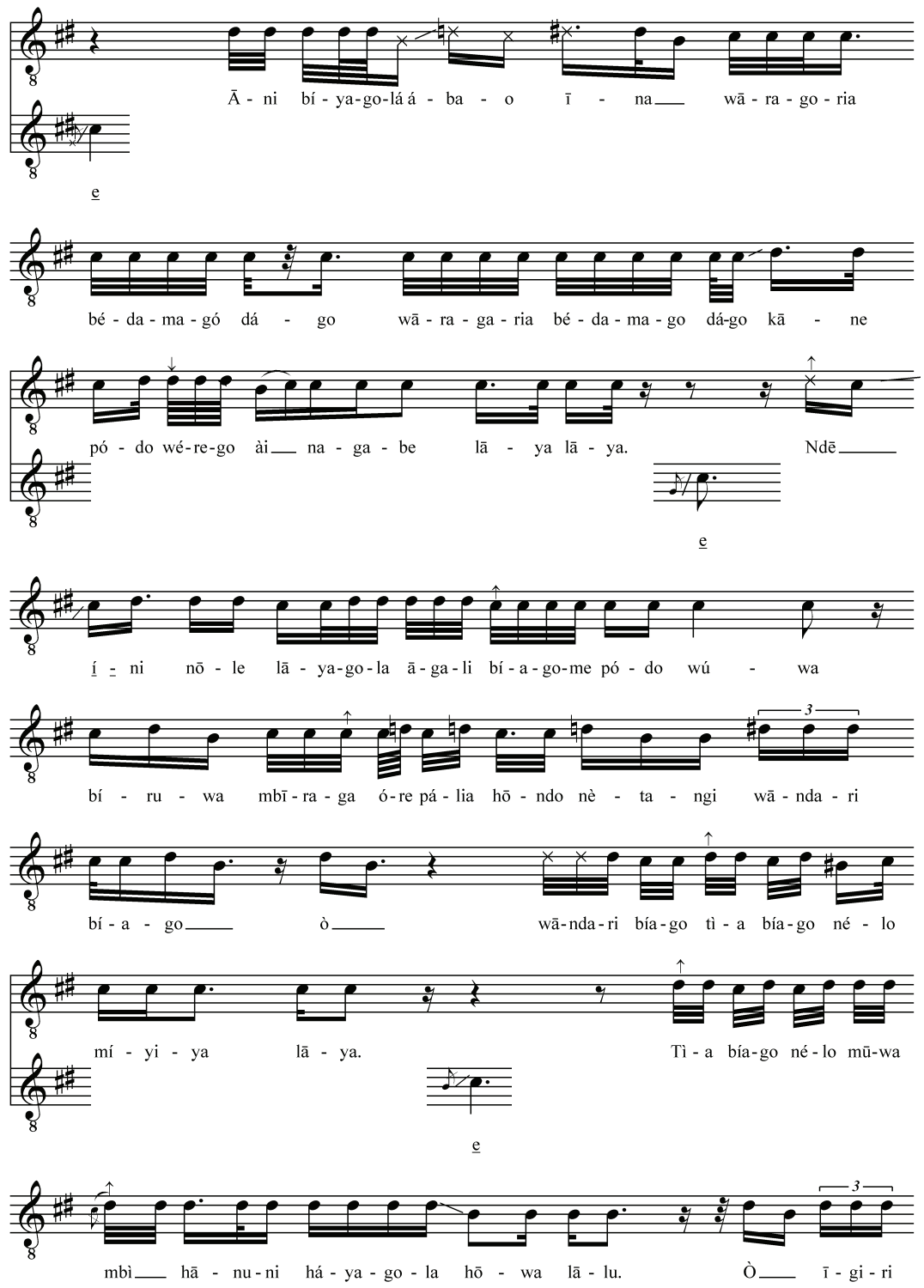

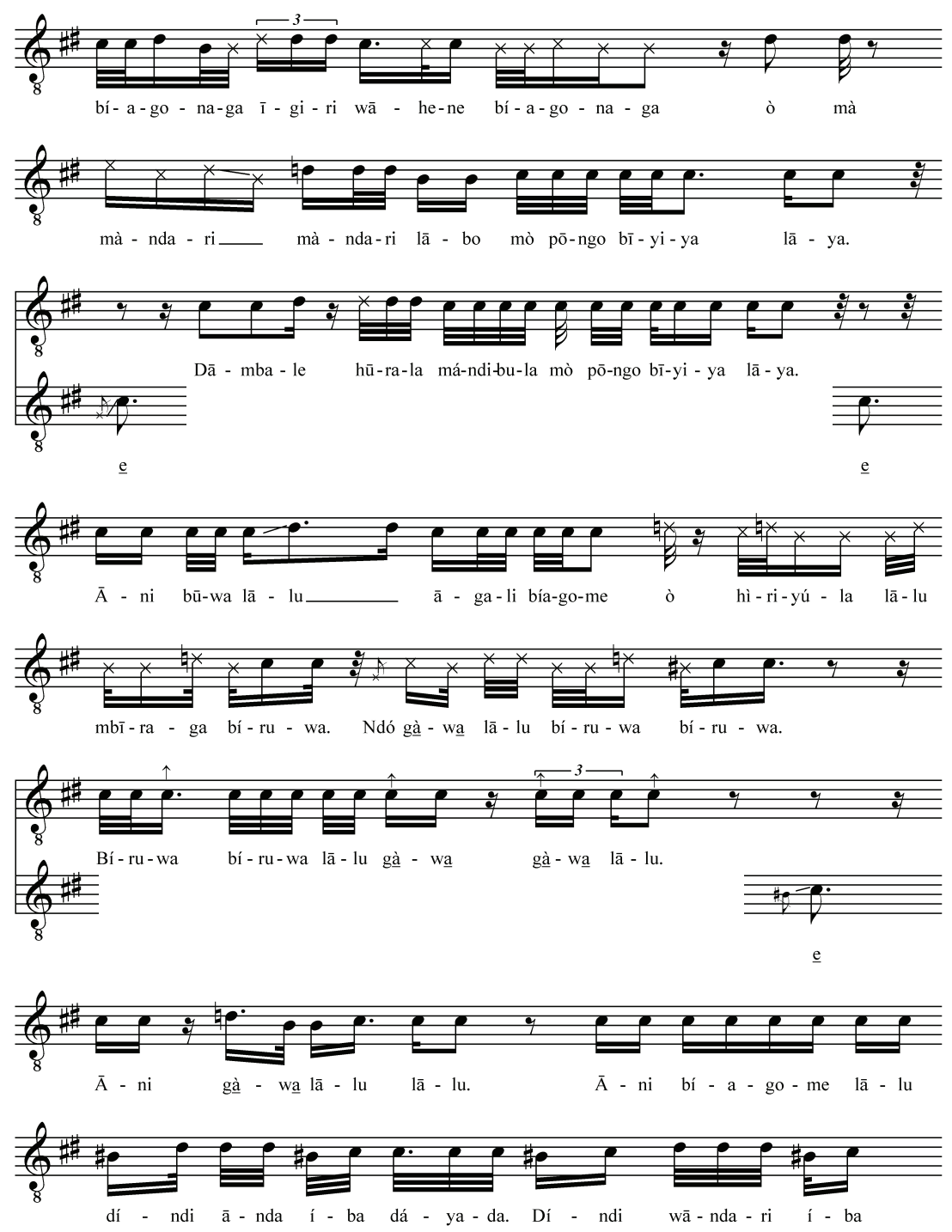
Sung Tales from the Papua New Guinea Highlands

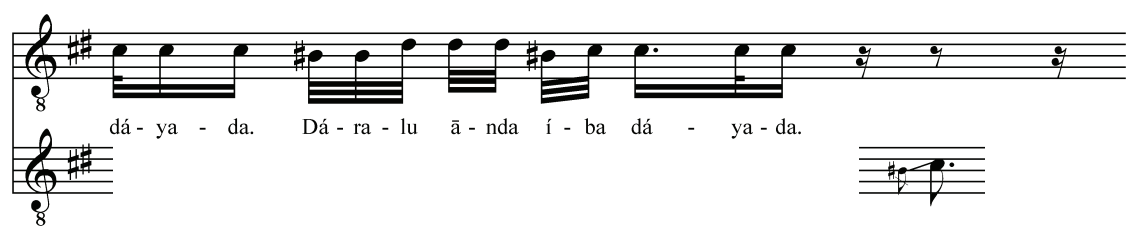

$\underline{\mathrm{e}}$
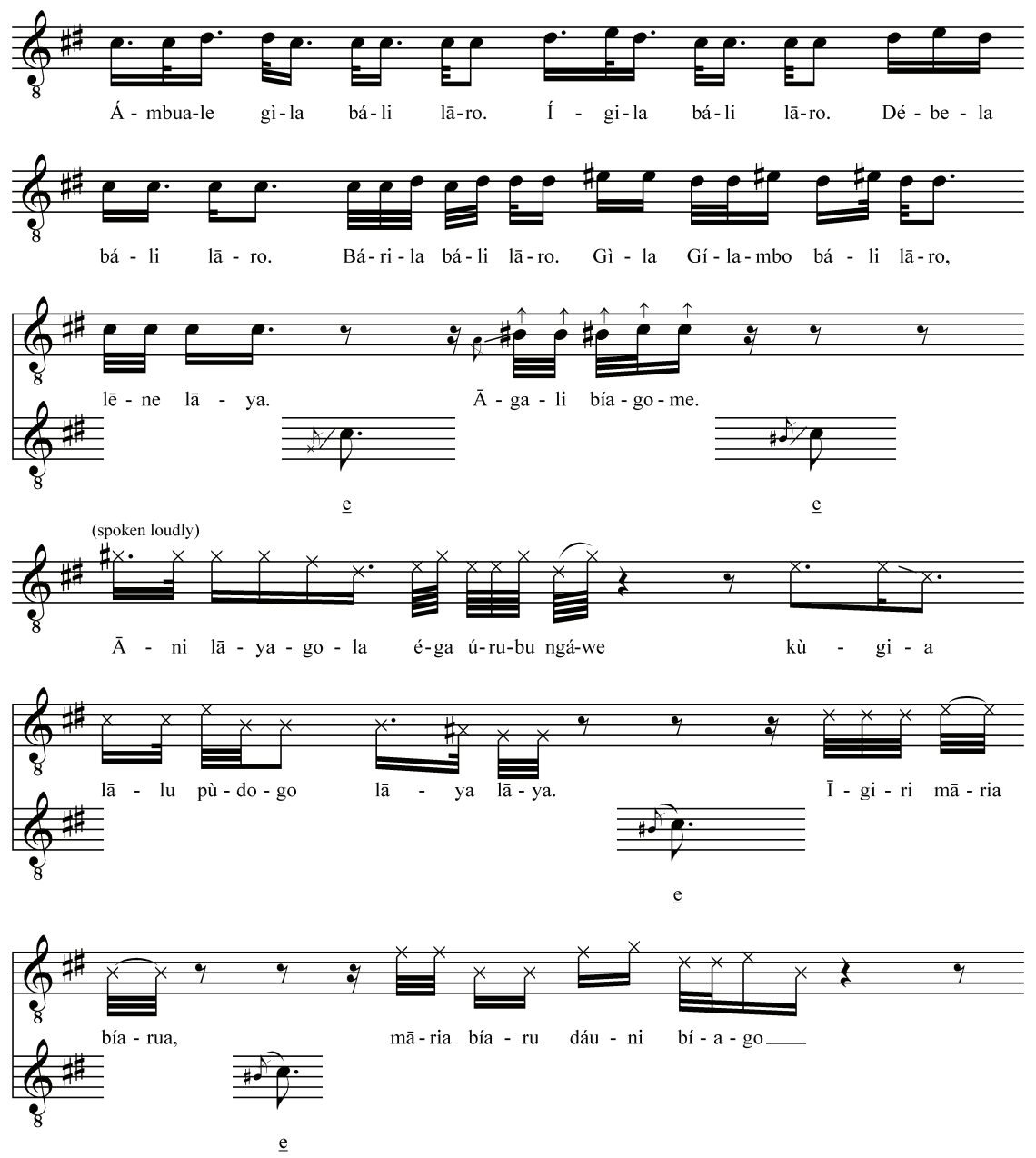
6. An Ethnomusicological Discussion of Bì Té
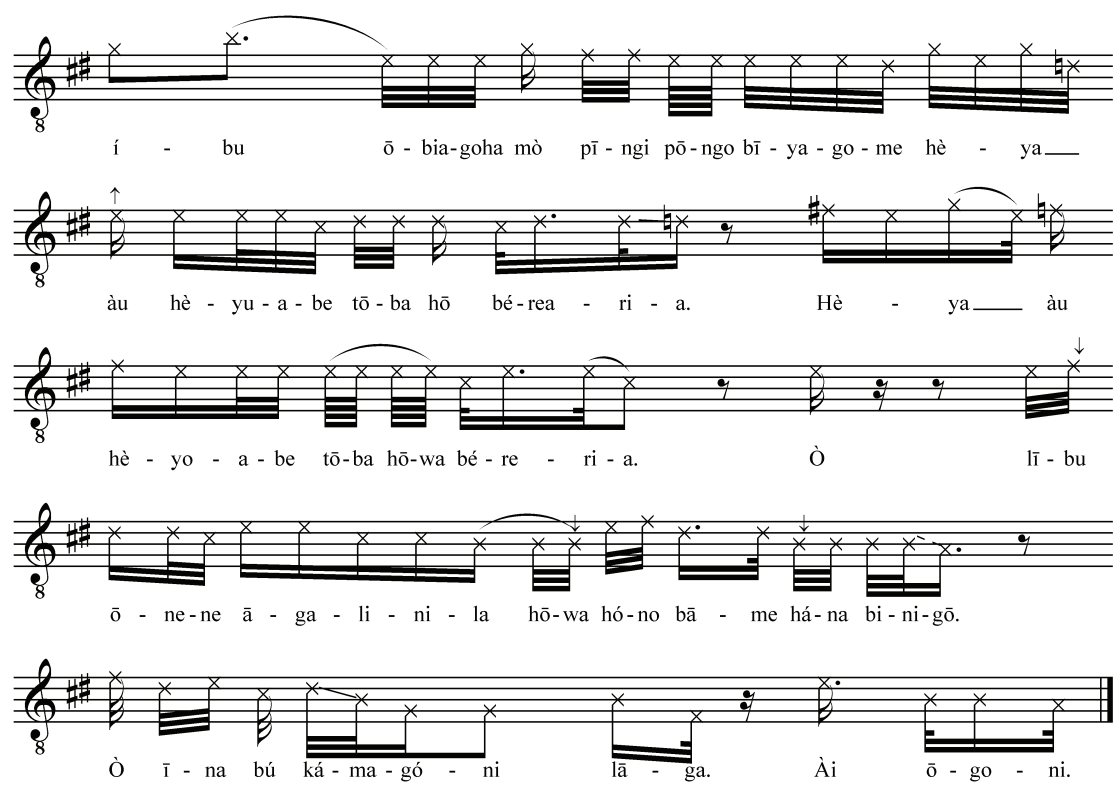
Bì té mbīra lārogo. Ndē húlu wāndari mbīra-ò, wāndari mbīra béreneya lāya. Story one I'm saying, see. So then person girl one-o, girl one was sitting said. Listen, I'm going to tell you a story. Once there was a girl, a girl was living there (said).

Ndē wāndari mbīra béreneyàgo, íbu ndē píyiya lāya. Pīalu hēaria, And then girl one which was sitting, she then went said. When she had gone she stayed, Then one day the girl who was living there went for a walk (said). When she had gone, she stopped

ài nē lāyagola. Āgali bālamānda mbīra winniyago, hánda wālia hōwa, then twilight because it was saying. Man man's house one which was there when she found, because night was approaching. She found a man's house there with bundles of

ōbíagoha dù mbāria mbúla hēago ānda pūwá, ōbíagoha birrayiya lāya. that place sugar-cane one tied up there house when went, that place she sat said. sugar cane tied up, and she sat down near that place (said).

Āni bíaria āgali wāhe mbīra ìra bòyalu ibuwa ìra ìbira háyiya lāya. Then while doing man old one wood carrying came wood came put down said. While she was there an old man came along carrying firewood, he came and put it down (said).

İra ibira háyagola ìra bíago gābiyaria hàrane mbīra púwa, wāndari bíago Wood came when put down wood that one while he chopped chip one went, girl that one While he was chopping the wood that he had brought, a chip flew off and struck that girl

bérearia pú bilina háyiya lāya. Āni bíyagola mànda āgali bíagome ìra hàrane while sitting go hit put down said. Then because it did that wig man that one wood chip who was sitting there (said). Because the chip flew off, the man (haroli) went to get it

bíago mò ài ibiyaria wāndari bíago hánda wāli háyiya lāya. Hánda wāli háyagola that one get then while he went girl that found said. When he found and in doing so he found that girl (said). When he found her, he picked her

íbu míni yálu púwa íbu iggini dúria yágo. Pāliaguha úlu wāhowa úlu her picked carried his sons five were. Place where to lide down hole found hole up and carried her to where his five "sons" (students) were. He found a hole where she could lie down

wāhowa bére lāyiya lāya. Bére lēaria ài ìgiri dúria bárume tìage tàya pēneyago tìabo found put into said. After putting into then boys five those cuscus hunt which went cuscus and put her there (said). When he had put her there, then thoe five youths who had gone hunting cuscus

hánalu ibiyiya lāya. Tìabo hānalu ibiyagola tìa bíago tìabo hánalu carried in bag came said. Cuscus carried in bag when they came cuscus that one cuscus carried in bag came bringing cuscus (said). When they brought the cuscus, that cuscus when they brought it, they gave it

ibiyagola tì ába íbu ába íbugua dáwelo míyiya lāya. Dáwelo mūwá when they came, their father he father he to cook gave said. To cook when had given to their father to cook (said). When they had given it

tìni dúria íbu ába íbu ò wāragane yágó káne pódo wíyiyá lāya. Āni bíyagolá they themselves five he father he o sixth was seventh cut placed said. When he did that to him to cook, he cut five pieces for them, he was the sixth and he cut a seventh (said). When he did that

ábao ìna wāragoria bédamagó dágo wāragariabédamago dágo kāne pódo wérego àinagabe "Father we six we sit (st. v.) see six we sit see seventh cut which you put whose? they said, "Father, there are six of us, six of us, whose is the seventh piece that you cut?" (said). 
lāya lāya. Ndē ini nōle lāyagola āgali biagome pódo wúwa, bíruwa they said said. So then "I myself I will eat" said therefore man that one cut put, waited So he said, "I myself will eat it," and he cut it and put it aside, and waited

mbīraga óre pália hōndo nètangi wāndaribíago ò wāndari bíago tìa bíago nélo míyiya night-time very asleep while girl that one o girl that one cuscus that one to eat gave until the middle of the night when they were sleeping to give that girl the cuscus (said).

lāya. Tìa biago nélo mūwa hānuni háyagola hōwa lālu. Ò ìgiri bíagonaga said. Cuscus that to eat when he had given midnight because it was staying said. O boy that one's When he had given her that cuscus to eat, it was midnight. Then he tied the long

ìgiri wāhene biagonaga ò mà màndari màndari lābo mò pōngo bīyiya lāya. Dāmbale hūrala boy eldest that one's o hair to hair to long tied said. Man's apron grass skirt\& hair of the eldest boy to the others' hair (said). He tied their dambales and

mándibula mò pōngo bīyiya lāya. Āni būwa lālu āgalibíagome ò hìriyúla lālu mbīraga bíruwa. waist strings\& tied together waist strings together (said). said. And then said man that one o hiriyula said night-time was sitting. Then that man sat playing hiriyula in the night.

Ndó gàwa lālu bíruwa bíruwa. Bíruwa bíruwa lālu gàwa gà̀wa lālu. Āni gàwa No gawa saying was sitting was sitting. Sitting was sitting saying gaw $\underline{a} \underline{a}$ gawa saying. Then gawa No, he was sitting there playing ga $\underline{a} \underline{a}$. He was sitting and playing gaw $\underline{a}$, he played gaw $\underline{a}$. Then he

lālu lālu. Āni biagome lālu díndi ānda íba dáyada. said said. Then that one said "Place house water flooded.

Díndi wāndari played gawa. Then while playing that one he said, "Water flooded the houses on the ground. Water flooded the

iba dáyada. Dáralu ānda iba dáyada. Ámbuale gìla báli lāro.

water flooded. Place house water flooded. Yellow decoration I'm saying.

girl on the ground. Water flooded the house at Daralu. I'm decorating in yellow.

Ígila báli lāro. Débela báli lāro. Bárila báli lāro. Gìla Gílambo

Place decoration I'm saying. Place decoration I'm saying. Pig decoration I'm saying. Places

I'm decorating Igila. I'm decorating Debela. I'm decorating pigs. I'm decorating

báli lāro, lēne lāya. Āgali bíagome. Āni lāyagola éga úrubu ngáwe kùgia

decoration I'm saying," he said said. Man that one. Then because he said parrots screeching

Gila and Gilambo," (said). $\quad$ That man (said it). Then because he said that parrots (in nearby trees)

lālu pùdogo lāya lāya. İgiri māria bíarua, māria bíaru dáuni bíago íbu ōbiagoha mò pīngi pōngo

flew away said. Boys four those four those fifth that one he in that place which were

flew away screeching. Those four young men, those four and that fifth, they were all tied together

bīyagome hèya àu hèyuabe? Hōbahō bérearia. Hèya àu hèyoabe?

tied together raised up how did they rise up? In a line they sat. Rise up how did they rise up?

so how could they rise up? They could only sit in a line. How could they rise up?

Tōba hōwa béreria. Ò lību ōnene āgalinila hōwa hóno bāme hána binigō.

In a line sat. O they wife husband\& staying, gave birth spread everywhere.

They sat in a line. Then those two became husband and wife, and their children spread everywhere.

Ò ìna bú kámagóni lāga. Ai ōgoni.

$\mathrm{O}$ we are born through as usually say. Then that's it.

We are descended from them as is said. That's all. 